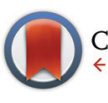

CrossMark $\leftarrow$ click for updates

Cite this: Dalton Trans., 2015, 44 17189

Received 4th August 2015,

Accepted 27th August 2015

DOI: $10.1039 / c 5 d t 02994 \mathrm{e}$

www.rsc.org/dalton

\section{Syntheses and properties of phosphine- substituted ruthenium(II) polypyridine complexes with nitrogen oxides $\uparrow$}

\author{
Go Nakamura, a,b Mio Kondo, ${ }^{a, b, c, d}$ Meredith Crisalli, ${ }^{\text {a }}$ Sze Koon Lee, ${ }^{a}$ Akane Shibata, ${ }^{a}$ \\ Peter C. Ford ${ }^{e}$ and Shigeyuki Masaoka*a,b,d
}

\begin{abstract}
Four novel phosphine-substituted ruthenium(II) polypyridine complexes with nitrogen oxides-trans-

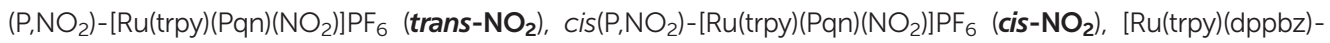

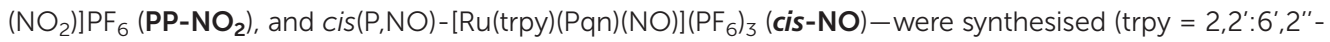
terpyridine, $\mathrm{Pqn}=8$-(diphenylphosphanyl)quinoline, and dppbz $=1,2$-bis(diphenylphosphanyl)benzene). The influence of the number and position of the phosphine group(s) on the electronic structure of these complexes was investigated using single-crystal X-ray structural analysis, UV-vis absorption spectroscopy, and electrochemical measurements. The substitution lability of the nitrogen oxide ligand of each complex is discussed in comparison with that of the corresponding acetonitrile complexes.
\end{abstract}

\section{Introduction}

Ruthenium(II) polypyridine complexes are widely studied materials because of their contributions to fundamental coordination chemistry, including electrochemistry, photochemistry, and photophysics, ${ }^{1}$ and their potential applications in energy conversion, ${ }^{2}$ luminescent sensors ${ }^{3}$ electroluminescence displays, ${ }^{4}$ and biotechnology. ${ }^{5}$ Of particular interest are the $\mathrm{Ru}(\mathrm{II})$ complexes $[\mathrm{Ru}(\mathrm{TL})(\mathrm{BL})(\mathrm{L})]^{n+}(\mathrm{TL}=$ tridentate polypyridine ligand, $\mathrm{BL}=$ bidentate polypyridine ligand, and $\mathrm{L}=$ monodentate labile ligand) given their catalytic activity for various reactions, such as oxidation, ${ }^{6,7}$ reduction, ${ }^{8-11}$ and photoinduced reactions. ${ }^{12}$

Phosphine-containing ruthenium(II) complexes are also attractive for potential applications in energy conversion systems $^{13}$ and catalysis ${ }^{14-17}$ owing to the $\sigma$-donating and

\footnotetext{
${ }^{a}$ Institute for Molecular Science (IMS), 5-1 Higashiyama, Myodaiji, Okazaki, Aichi 444-8787, Japan. E-mail: masaoka@ims.ac.jp; Fax: +81-564-59-5589

${ }^{b}$ Department of Structural Molecular Science, School of Physical Sciences, SOKENDAI (The Graduate University for Advanced Studies), Shonan Village, Hayama-cho, Kanagawa 240-0193, Japan

${ }^{c}$ ACT-C, Japan Science and Technology Agency (JST), 4-1-8 Honcho, Kawaguchi, Saitama 332-0012, Japan

${ }^{d}$ Research Center of Integrative Molecular Systems (CIMOS), Institute for Molecular Science, 38 Nishigo-naka, Myodaiji, Okazaki, Aichi 444-8585, Japan

${ }^{e}$ Department of Chemistry and Biochemistry, University of California at Santa Barbara, Santa Barbara, California 93106-9510, USA

$\dagger$ Electronic supplementary information (ESI) available. CCDC 1040452-1040454. For ESI and crystallographic data in CIF or other electronic format see DOI: 10.1039/c5dt02994e
}

$\pi$-accepting abilities of the phosphine ligands. Thus, it should be possible to develop ruthenium complexes that have novel and tunable properties and reactivity by designing mixed polypyridyl/phosphine complexes. There have been several reports on the syntheses of ruthenium(II) polypyridine complexes containing monodentate phosphine ligands ${ }^{16,18,19}$ and their catalytic activities. ${ }^{19 d, 20}$ However, ruthenium(II) polypyridine complexes of the type $[\mathrm{Ru}(\mathrm{TL})(\mathrm{BL})(\mathrm{L})]^{n+}$ bearing bidentate ligands with $\mathrm{P}$ and $\mathrm{N}$ donors have not been investigated.

In our previous report, ${ }^{21}$ we synthesised and structurally characterised for the first time a series of phosphine-containing ruthenium(II) polypyridine complexes of the type $[\mathrm{Ru}(\mathrm{TL})$ $(\mathrm{BL})(\mathrm{L})]^{n+}$, with $\mathrm{L}=$ acetonitrile, $\mathrm{TL}=2,2^{\prime}: 6^{\prime}, 2^{\prime \prime}$-terpyridine (trpy), and $\mathrm{BL}=8$-(diphenylphosphanyl)quinoline (Pqn) or 1,2-bis(diphenylphosphanyl)benzene (dppbz) (Scheme 1). The influence of the number and position of phosphine donors on the structures and electronic properties was characterised, and unique isomerisation behaviours of these complexes were observed. The coordinating phosphorus ligands played a crucial role in these isomerisation reactions, and the results encouraged us to investigate in more detail the influence of the $\mathrm{P}$ atom on the physical properties of Ru-based metal complexes.

In this study, we investigated the reaction of phosphinecontaining ruthenium complexes with the nitrogen oxides, NO and $\mathrm{NO}_{2}{ }^{-}$, because of their biological roles as signalling molecules ${ }^{22}$ and reservoirs, ${ }^{23}$ in addition to the fundamental interest in their coordination chemistry. Here, we show the syntheses, structural characterisation, and electrochemical and spectroscopic properties of a series of ruthenium(II) 


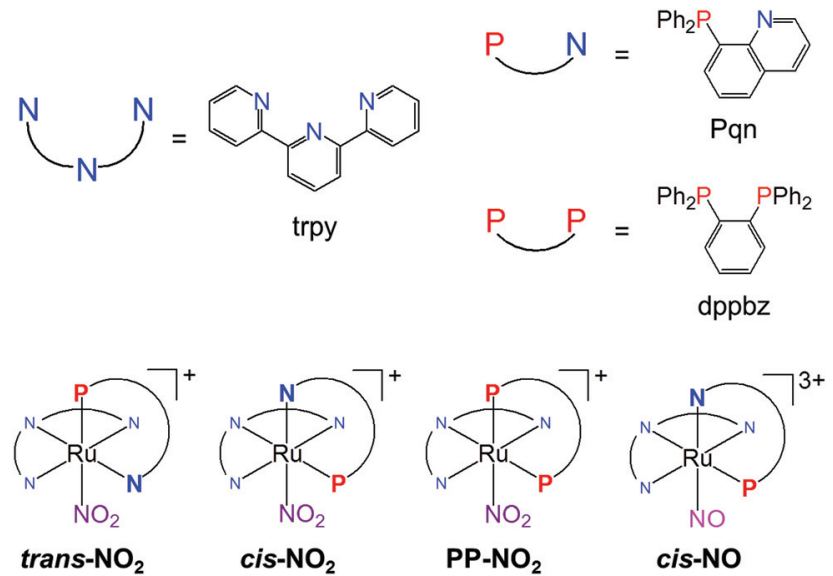

Scheme 1 Structures of a tridentate ligand (trpy), bidentate ligands (Pqn and dppbz), and metal complexes (trans- $\mathrm{NO}_{2}$, cis- $\mathrm{NO}_{2}, \mathrm{PP}-\mathrm{NO}_{2}$, and cis-NO) used in this study.

polypyridine complexes containing Pqn or dppbz with nitric oxides. Three novel nitrito- $\mathrm{K} N$ complexes- $\operatorname{trans}\left(\mathrm{P}, \mathrm{NO}_{2}\right)$ - and cis $\left(\mathrm{P}, \mathrm{NO}_{2}\right)-\left[\mathrm{Ru}\left(\right.\right.$ trpy)$\left.(\mathrm{Pqn})\left(\mathrm{NO}_{2}\right)\right] \mathrm{PF}_{6}$ (trans- $\mathrm{NO}_{2}$ and cis- $\left.\mathrm{NO}_{2}\right)$, and $\left[\mathrm{Ru}(\operatorname{trpy})(\mathrm{dppbz})\left(\mathrm{NO}_{2}\right)\right] \mathrm{PF}_{6} \quad\left(\mathbf{P P}-\mathrm{NO}_{2}\right)$-were successfully synthesised. Described here are the single-crystal X-ray structural determinations, UV-vis absorption spectra, and electrochemical measurements for these complexes, and the preparation of the nitrosyl complex cis(P,NO)-[Ru(trpy)(Pqn)$(\mathrm{NO})]\left(\mathrm{PF}_{6}\right)_{3}$ (cis-NO) from cis- $\mathrm{NO}_{2}$ and its properties are examined. The present study allows us to probe systematically the chemical and structural properties of phosphine-containing ruthenium complexes with nitrogen oxides by the use of the geometric isomers of the Pqn complex. Additionally, other reactivity properties and comparisons with those of the corresponding acetonitrile complexes are presented.

\section{Results and discussion}

\section{Syntheses and characterisation}

The synthetic procedures to obtain trans $-\mathbf{N O}_{2}, \boldsymbol{c i s}-\mathbf{N O}_{2}$, and PP-NO $\mathbf{N}_{2}$ are shown in Scheme 2. The precursors, trans-MeCN, cis-MeCN, and PP-MeCN, were synthesised according to the method that we previously reported. ${ }^{21}$ The reaction of the respective acetonitrile complexes with excess $\mathrm{NaNO}_{2}$ in a 1:1 mixture of ethanol:water at $100{ }^{\circ} \mathrm{C}$ gave the corresponding nitrito- $\mathrm{kN}$ complexes (trans- $\mathrm{NO}_{2}, \quad$ cis- $\mathrm{NO}_{2}$, and PP-NO $\left.\mathbf{N}_{2}\right){ }^{24,26 b}$ The resulting products were characterised by ${ }^{1} \mathrm{H}$ NMR and ${ }^{31} \mathrm{P}\left\{{ }^{1} \mathrm{H}\right\}$ NMR spectroscopy and elemental analysis.

The ${ }^{31} \mathrm{P}\left\{{ }^{1} \mathrm{H}\right\}$ NMR spectra of trans $-\mathrm{NO}_{2}$ and cis- $\mathrm{NO}_{2}$ in $\mathrm{CD}_{3} \mathrm{CN}$ displayed singlets at $\delta 53.10$ and 54.06, respectively, showing upfield shifts $(\Delta \delta=5.70$ and 1.90) compared to the spectra of the corresponding acetonitrile complexes, transMeCN and cis-MeCN ( $\delta 58.80$ and 55.96). The ${ }^{31} \mathrm{P}\left\{{ }^{1} \mathrm{H}\right\}$ NMR spectrum of $\mathbf{P P}-\mathrm{NO}_{2}$ in $\mathrm{CD}_{3} \mathrm{CN}$ afforded two doublets at $\delta 62.65$ and 68.59 with coupling constants of $14.2 \mathrm{~Hz}$, again

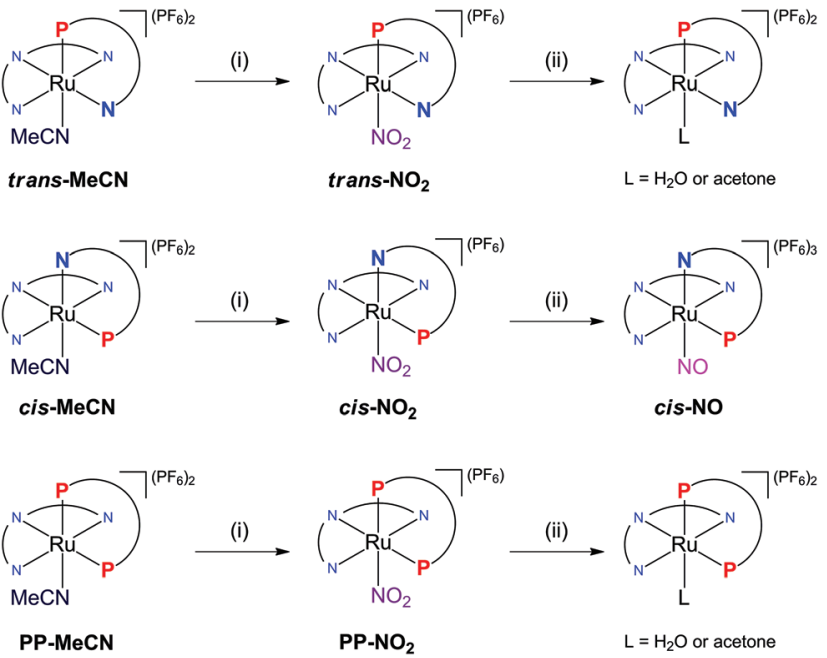

Scheme 2 Syntheses of trans $-\mathrm{NO}_{2}$, cis- $\mathrm{NO}_{2}, \mathrm{PP}-\mathrm{NO}_{2}$, and cis-NO. (i) $\mathrm{NaNO}_{2}$ in a 1:1 mixture of ethanol: water at $100{ }^{\circ} \mathrm{C}$. (ii) $\mathrm{HPF}_{6}$ in acetone at $0^{\circ} \mathrm{C}$.

showing upfield shifts ( $\Delta \delta=5.85$ and 1.18, respectively) compared with the spectrum of PP-MeCN (68.57 and 69.77, ${ }^{2} J_{\mathrm{P}-\mathrm{P}}=$ $20.2 \mathrm{~Hz}$ ).

Conversions of the nitrito-kN complexes to the corresponding ruthenium nitrosyls were attempted by adding an excess of $\mathrm{HPF}_{6}$ to acetone solutions of the nitrito- $\mathrm{KN}$ species at $0{ }^{\circ} \mathrm{C}$. The preparations of trans-NO and PP-NO from trans- $\mathrm{NO}_{2}$ and $\mathbf{P P}-\mathbf{N O}_{2}$, respectively, were not successful because of the instability of the nitrosyl complex or of a reaction intermediate under acidic conditions (for details, see Fig. S1 and S2 in the ESI†). However, cis-NO was isolated in $85 \%$ yield and was characterised by ${ }^{1} \mathrm{H}$ and ${ }^{31} \mathrm{P}\left\{{ }^{1} \mathrm{H}\right\}$ NMR spectroscopy and elemental analysis. The ${ }^{31} \mathrm{P}\left\{{ }^{1} \mathrm{H}\right\}$ NMR spectrum of cis-NO in acetone- $d_{6}$ gave a singlet at $\delta 54.23$. cis-NO immediately converted to a solvent-coordinated complex in acetonitrile (Fig. S3 in the ESI $\dagger$ ) but was meta-stable in weaker-coordinating solvents, such as acetone, $\gamma$-butyrolactone and ethylene glycol (Fig. S4 in the ESI $\dagger$ ). The difference in the stability of these nitrosyl complexes will be discussed in the "Substitution lability of nitrogen oxide" section.

\section{Crystal structures}

Single crystals of trans- $\mathrm{NO}_{2}$ and $\mathbf{P P}-\mathrm{NO}_{2}$ suitable for structural determination were obtained by recrystallisation from diethyl ether/methanol/acetonitrile. Single crystals of the cis-nitrito-kN complex were obtained as the $\mathrm{BPh}_{4}{ }^{-}$salt, $\operatorname{cis}\left(\mathrm{P}, \mathrm{NO}_{2}\right)-[\mathrm{Ru}(\operatorname{trpy})$ $\left.(\mathrm{Pqn})\left(\mathrm{NO}_{2}\right)\right] \mathrm{BPh}_{4}\left(\boldsymbol{c i s}\right.$ - $\left.\mathrm{NO}_{2}{ }^{\prime}\right)$, by adding an excess of $\mathrm{NaBPh}_{4}$, instead of $\mathrm{NH}_{4} \mathrm{PF}_{6}$, after the reaction. The molecular structures of trans $-\mathrm{NO}_{2}$, cis- $\mathrm{NO}_{2}{ }_{2}$, and $\mathbf{P P}-\mathrm{NO}_{2}$ determined by singlecrystal X-ray crystallography and the summary of crystallographic data are shown in Fig. 1 and Table 1, respectively. The asymmetric unit of the monoclinic $P 2_{1} / n$ crystal of trans $-\mathrm{NO}_{2}$ contained one cationic ruthenium complex, one $\mathrm{PF}_{6}$ anion, and one acetonitrile molecule. The cis- $\mathrm{NO}_{2}{ }^{\prime}$ crystallised with 

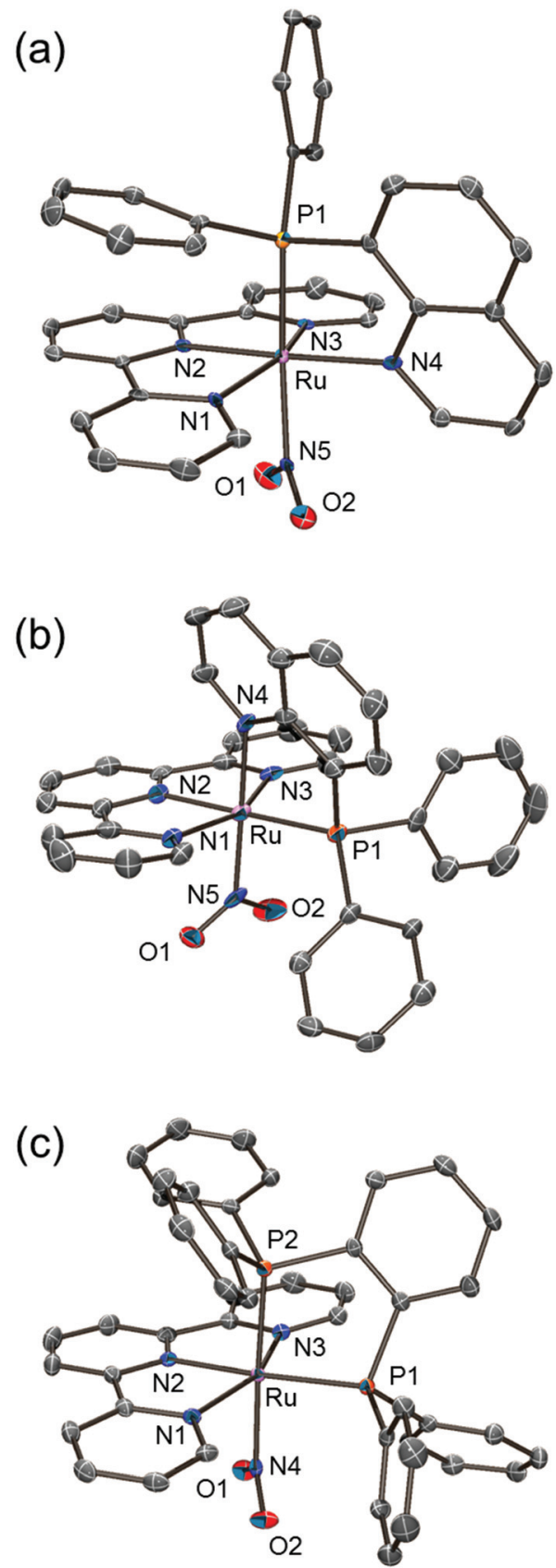

Fig. 1 ORTEP drawings (50\% probability level) of cationic complexes in (a) trans $-\mathrm{NO}_{2}$, (b) cis- $\mathrm{NO}_{2}{ }^{\prime}$, and (c) PP- $\mathrm{NO}_{2}$. Hydrogen atoms are omitted for clarity.

two crystallographically independent ruthenium complexes, two $\mathrm{BPh}_{4}{ }^{-}$anions, and one acetonitrile molecule as the crystal solvent in the asymmetric unit of the triclinic $P 1$ space group. The asymmetric unit of the monoclinic $P 2_{1} / c$ crystal of $\mathbf{P P}-\mathbf{N O}_{2}$ contained one cationic ruthenium complex, one $\mathrm{PF}_{6}$ anion, and two methanol molecules. For each complex, the ratio of ruthenium to counter anion indicated that the oxidation state of the ruthenium centre was +2 . The coordination geometry of each $\mathrm{Ru}$ atom was that of a distorted octahedron composed of a meridionally coordinated terpyridine ligand, a bidentate ligand, and a nitrito ligand.

The bond distances between the ruthenium and nitrogen atoms of the nitrito ligand of trans $-\mathbf{N O}_{2}$ and $\mathbf{P P}-\mathbf{N O}_{2}$ were 2.146(4) (Ru1-N5) and 2.124(2) ^ (Ru1-N4), respectively (Fig. 2), and were longer than those found in $[\mathrm{Ru}(\mathrm{trpy})(\mathrm{bpm})$ $\left.\left(\mathrm{NO}_{2}\right)\right] \mathrm{PF}_{6}\left(2.034(5) \AA\right.$, bpm $=2,2^{\prime}$-bipyrimidine $) .{ }^{25}$ By contrast, the $\mathrm{Ru}-\mathrm{N}\left(\mathrm{NO}_{2}\right)$ distances in cis- $\mathrm{NO}_{2}{ }^{\prime}$ (2.0362(18) and 2.0290 (18) $\AA$ for Ru1-N5 and Ru2-N10, respectively, Fig. 2) were similar to those of $\left[\mathrm{Ru}(\operatorname{trpy})(\mathrm{bpm})\left(\mathrm{NO}_{2}\right)\right] \mathrm{PF}_{6}(2.034(5) \AA)$. These results indicated a stronger trans influence of the phosphorus atom of Pqn or dppbz compared with that of the nitrogen atom of bpm or bpy. This tendency was also observed in transMeCN, cis-MeCN, and PP-MeCN in our previous study. ${ }^{21}$

\section{UV-vis absorption spectra}

Fig. 3 shows the UV-Vis absorption spectra of the nitrito- $\kappa N$ complexes, trans $-\mathbf{N O}_{2}$, cis- $\mathbf{N O} \mathbf{O}_{2}$, and $\mathbf{P P}-\mathbf{N O}_{2}$, in acetonitrile solution. The spectral data for these complexes and related compounds are listed in Table 2. All complexes displayed intense absorption bands in the UV region that were assigned to ligand-based $\pi-\pi^{*}$ transitions. Additionally, a moderately intense band was observed in the visible region for each complex. TD-DFT calculations that were performed at the B3LYP/LANL2DZ and B3LYP/SDD level of theory indicated that the visible region band could be assigned to metal-to-ligand charge transfer (MLCT) transitions from the $\mathrm{d} \pi$ orbitals of ruthenium to the $\pi^{*}$ orbitals of trpy and Pqn or dppbz (for details, see Table S1 and Fig. S5-9 in the ESI $\dagger$ ). The molar absorption coefficient of $\mathbf{P P}-\mathbf{N O}_{2}$ was nearly half of those of trans $-\mathrm{NO}_{2}$ and $\boldsymbol{c i s}-\mathrm{NO}_{2}$. The absorption maximum $\left(\lambda_{\max }\right)$ of the MLCT transition of trans- $\mathbf{N O}_{2}$, cis- $\mathbf{N O}_{2}$, and $\mathbf{P P}-\mathbf{N O}_{2}$ was 443, 431, and $402 \mathrm{~nm}$, respectively, and was blue-shifted compared with that of $\left[\mathrm{Ru}(\operatorname{trpy})(\mathrm{bpm})\left(\mathrm{NO}_{2}\right)\right] \mathrm{PF}_{6},{ }^{25}$ suggesting the stabilisation of the $\mathrm{d} \pi$ orbitals of the ruthenium centre upon introduction of the phosphine donors. Note that the MLCT band of cis- $\mathbf{N O}_{2}$ was more blue-shifted than that of trans $-\mathbf{N O}_{2}$ despite their isomeric relationship. A similar pattern was noted for the acetonitrile complexes, trans-MeCN, cis-MeCN, and PP-MeCN. ${ }^{21}$

The UV-vis absorption spectra of the cis-isomers with different ligands $\mathrm{L}$, $\operatorname{cis}(\mathrm{P}, \mathrm{L})-[\mathrm{Ru}(\operatorname{trpy})(\mathrm{Pqn})(\mathrm{L})]^{n+}\left(\mathrm{L}=\mathrm{Cl}^{-}, \mathrm{NO}_{2}{ }^{-}\right.$, $\mathrm{MeCN}$, and $\mathrm{NO}^{+}$), in ethylene glycol solution are shown in Fig. 4. These complexes each exhibited ligand-based $\pi-\pi^{*}$ transitions in the UV region and MLCT transitions in the visible region. The MLCT transition of cis-NO was observed at $\lambda_{\max }=$ $383 \mathrm{~nm}$ and is comparable to similar $\mathrm{Ru}-\mathrm{NO}$ complexes (Table 3). For the different Ls, the lowest energy MLCT bands of the cis-isomers are in the following order: $\mathrm{L}=\mathrm{Cl}^{-}(468 \mathrm{~nm})$ $<\mathrm{NO}_{2}{ }^{-}(423 \mathrm{~nm})<\mathrm{MeCN}(413 \mathrm{~nm})<\mathrm{NO}^{+}(383 \mathrm{~nm})$. This result can be attributed to the competing $\sigma$-donor $/ \pi$-acceptor properties of the respective ligands.

\section{Electrochemical properties}

The cyclic voltammograms (CVs) of trans- $\mathrm{NO}_{2}$, cis- $\mathrm{NO}_{2}$, and PP-NO $\mathrm{N}_{2}$ are shown in Fig. 5, and electrochemical data for these 
Table 1 Crystallographic data for trans $-\mathrm{NO}_{2}$, cis $-\mathrm{NO}_{2}{ }^{\prime}$, and $\mathrm{PP}-\mathrm{NO}_{2}$

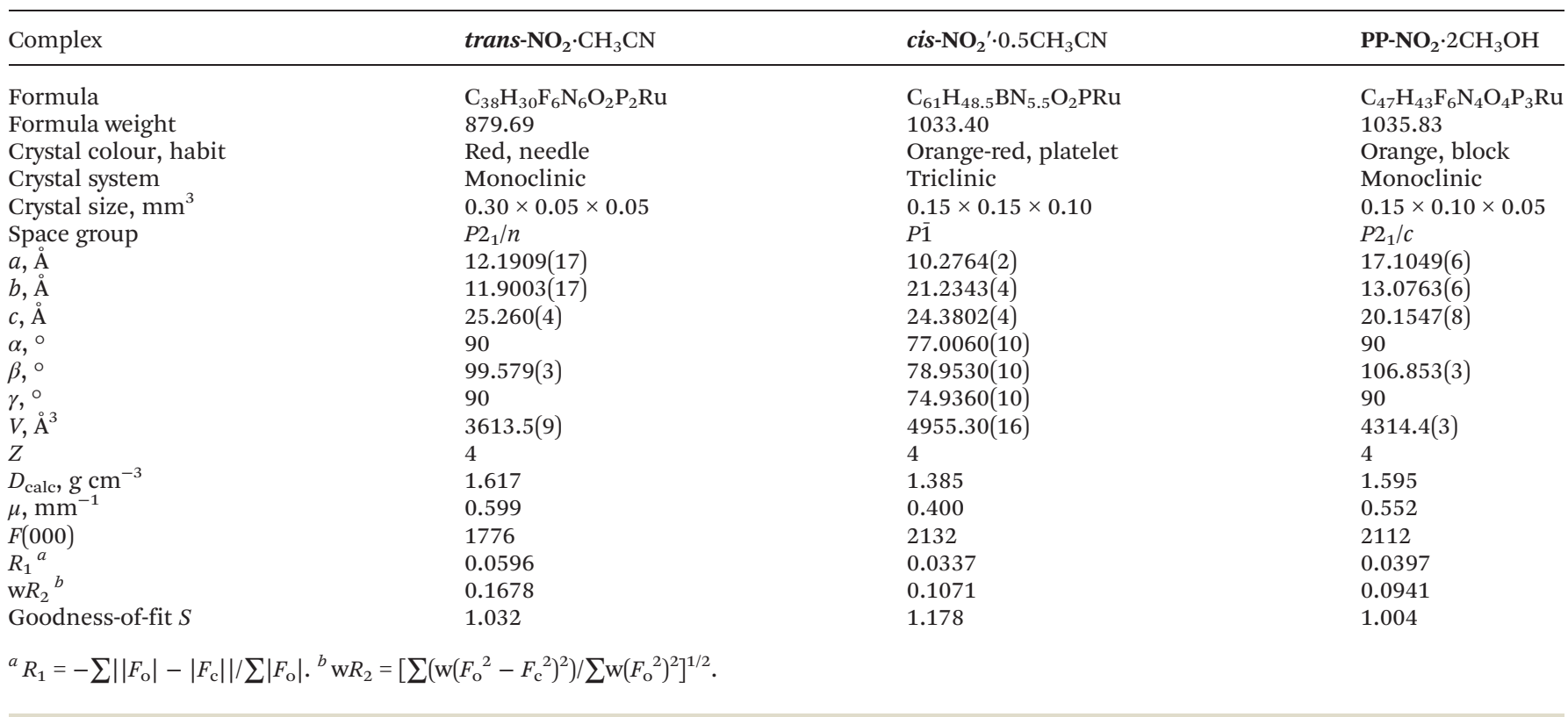

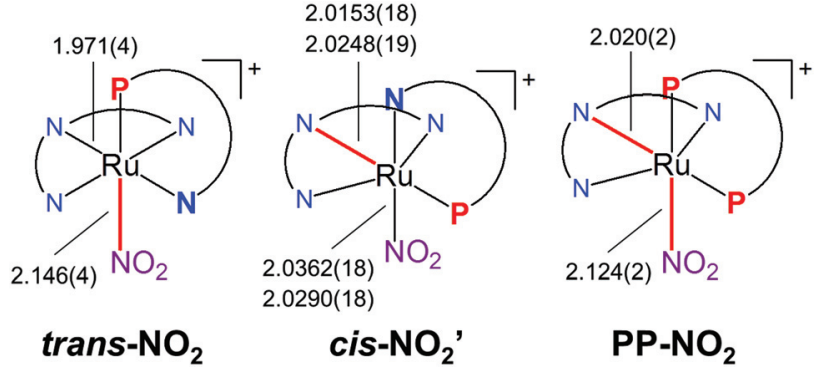

Fig. 2 Comparison of bond distances $(\AA)$ around the ruthenium centres of trans- $\mathrm{NO}_{2}$, cis $-\mathrm{NO}_{2}{ }^{\prime}$, and PP- $\mathrm{NO}_{2}$.

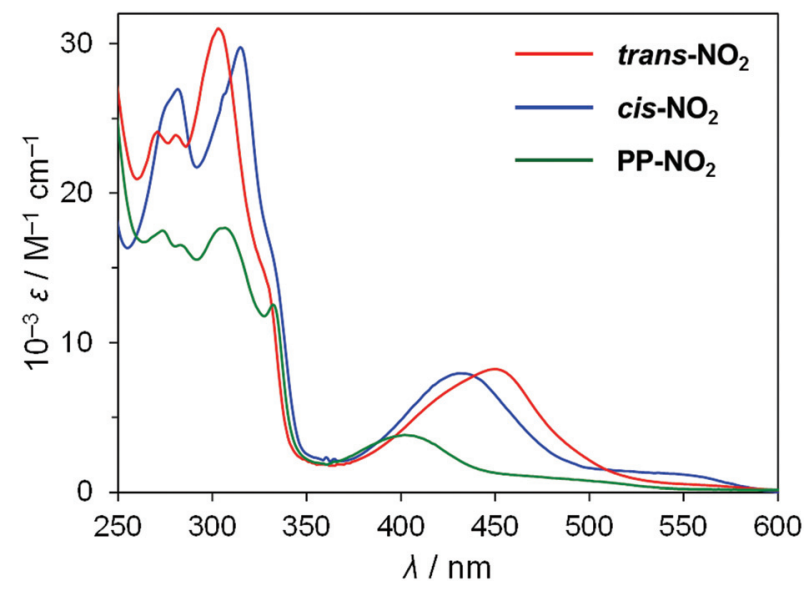

Fig. 3 UV-Vis absorption spectra of trans $-\mathrm{NO}_{2}$, cis- $-\mathrm{NO}_{2}$, and $\mathrm{PP}-\mathrm{NO}_{2}$ in acetonitrile at room temperature. complexes and related compounds are listed in Table 4. The CVs were measured in $0.1 \mathrm{M}$ tetraethylammonium perchlorate (TEAP)/acetonitrile. cis- $\mathrm{NO}_{2}$ displayed one reversible oxidation wave in the positive region at $E_{1 / 2}=0.79 \mathrm{~V} v s$. ferrocene/ferrocenium $\left(\mathrm{Fc} / \mathrm{Fc}^{+}\right)$, which was assigned to a $\mathrm{Ru}(\mathrm{III}) / \mathrm{Ru}(\mathrm{II})$ redox couple. By contrast, trans- $\mathrm{NO}_{2}$ and $\mathbf{P P}-\mathrm{NO}_{2}$ exhibited one irreversible $\left(E_{\mathrm{pa}}=0.79\right.$ for trans $-\mathrm{NO}_{2}$ and $0.95 \mathrm{~V}$ for $\left.\mathbf{P P}-\mathrm{NO}_{2}\right)$ and one reversible $\left(E_{1 / 2}=0.97\right.$ for trans $-\mathbf{N O}_{2}$ and $1.27 \mathrm{~V}$ for $\left.\mathbf{P P}-\mathrm{NO}_{2}\right)$ redox waves in the positive region. The former irreversible oxidation peak can be attributed to oxidation of the $\left(\mathrm{Ru}-\mathrm{NO}_{2}\right)^{+}$ centre, and the latter reversible wave was observed exactly at the same potential as the $\mathrm{Ru}(\mathrm{III}) / \mathrm{Ru}$ (II) redox couple of the corresponding acetonitrile complex $\left(E_{1 / 2}=0.97\right.$ for transMeCN and 1.27 V for PP-MeCN, Table 4 and Fig. S10b and S10d in the ESI $\dagger$ ). ${ }^{21}$ These observations suggest that the one-electron oxidation of trans- $\mathbf{N O}_{2}$ and $\mathbf{P P -} \mathbf{N O}_{2}$ results in the release of $\mathrm{NO}_{2}$, owing to the labilising effect of the trans-phosphine in each case. This leads to the formation of the respective ruthenium(II) acetonitrile complexes, which are oxidised reversibly on further sweep to more positive potential (Scheme 3). In the absence of a trans-labilising phosphine, the oxidation of the $\left(\mathrm{Ru}-\mathrm{NO}_{2}\right)^{+}$centre of $\boldsymbol{c i s}-\mathrm{NO}_{2}$ occurs at a similar potential to the trans-isomer, but reversibly (Fig. 5 and Table 4).

In the negative potential region, cis- $\mathbf{N O}_{2}$ displayed two reversible reduction waves at -1.70 and $-1.99 \mathrm{~V}$, which were assigned to the trpy/trpy ${ }^{-}$and $\mathrm{Pqn} / \mathrm{Pqn}^{-}$redox couple, respectively. trans $-\mathrm{NO}_{2}$ exhibited two redox waves at $E_{1 / 2}=-1.77$ and $-2.13 \mathrm{~V}$, and these redox potentials were the same as that of trans-MeCN (Table 4 and Fig. S10a in the ESI + ). PP-NO ${ }_{2}$ displayed two irreversible waves $\left(E_{\mathrm{pc}}=-1.70 \mathrm{~V}\right.$ and $\left.E_{\mathrm{pa}}=-1.47 \mathrm{~V}\right)$ and one reversible $\left(E_{1 / 2}=-2.49 \mathrm{~V}\right)$ redox wave in the negative region. The reversible wave at $E_{1 / 2}=-2.49 \mathrm{~V}$ and the 
Table 2 UV-Vis absorption data $\left(\lambda_{\max } / \mathrm{nm}\left(10^{-3} \varepsilon / \mathrm{M}^{-1} \mathrm{~cm}^{-1}\right)\right)$ in acetonitrile and infrared data $\left(\mathrm{v} / \mathrm{cm}^{-1}\right)$ for trans- $\mathrm{NO}_{2}$, cis- $\mathrm{NO}_{2}$, PP-NO compounds at room temperature

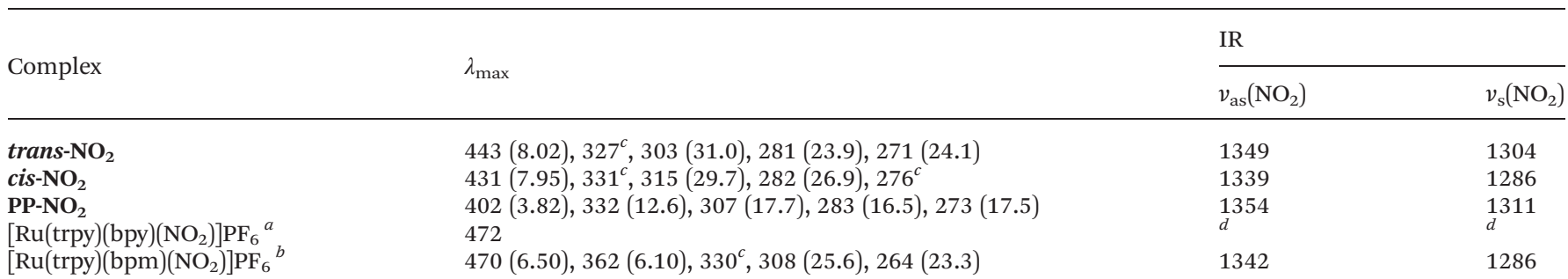

${ }^{a}$ Ref. 26. ${ }^{b}$ Ref. $25 .{ }^{c}$ Absorption shoulder. ${ }^{d}$ Data not collected.

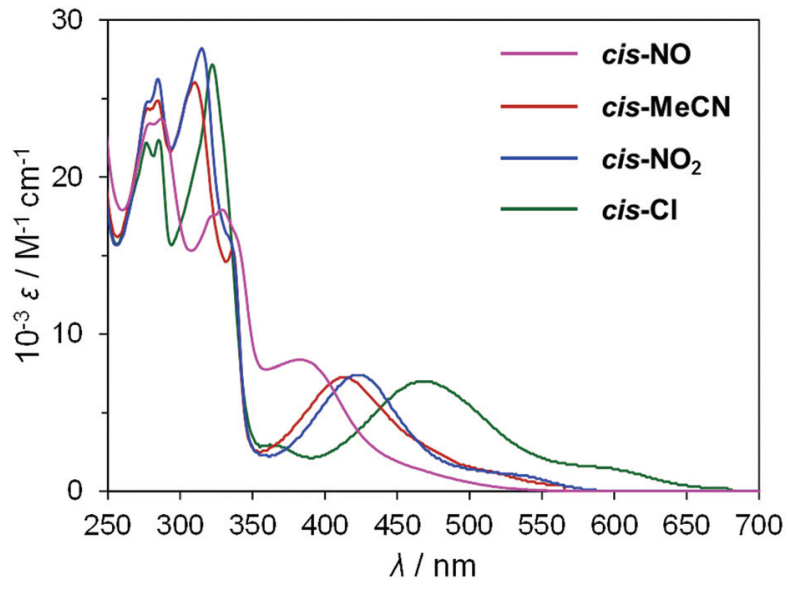

Fig. 4 UV-Vis absorption spectra of $\operatorname{cis}(\mathrm{P}, \mathrm{X})-[\mathrm{Ru}(\operatorname{trpy})(\mathrm{Pqn})(\mathrm{L})]^{n}\left(\mathrm{~L}=\mathrm{Cl}^{-}\right.$, $\mathrm{NO}_{2}{ }^{-}, \mathrm{MeCN}, \mathrm{NO}^{+}$) in ethylene glycol at room temperature.

irreversible anodic wave at $E_{\mathrm{pa}}=-1.47 \mathrm{~V}$ were similar to those observed for PP-MeCN (Table 4 and Fig. S10c in the ESI $\dagger$ ). These redox behaviours of trans $-\mathbf{N O}_{2}$ and $\mathbf{P P}-\mathbf{N O}_{2}$ revealed that the reduction of these complexes induced the dissociation of $\mathrm{NO}_{2}{ }^{-}$and the formation of MeCN-coordinated species; this behaviour was similar to that observed in the positive potential region. The electrochemical behaviours of the nitrito- $\mathrm{k} N$ complexes are summarised in Scheme 3.

cis-NO displayed one reversible redox wave at $E_{1 / 2}=0.05 \mathrm{~V}$ and one irreversible reduction peak at $E_{\mathrm{pc}}=-0.61 \mathrm{~V}$ (Fig. 6). Comparison with similar nitrosyl compounds ${ }^{24,25}$ revealed that the former redox wave was attributed to the $\mathrm{NO}^{+} / \mathrm{NO}^{\circ}$ redox

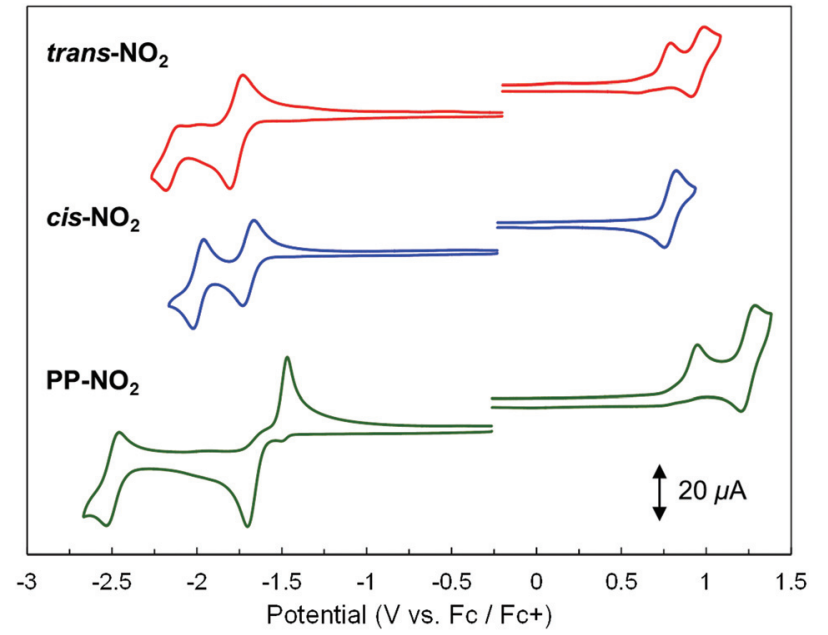

Fig. 5 Cyclic voltammograms of trans $-\mathrm{NO}_{2}$, cis $-\mathrm{NO}_{2}$, and $\mathrm{PP}-\mathrm{NO}_{2}$ $(0.5 \mathrm{mM})$ in $0.1 \mathrm{M} \mathrm{TEAP/acetonitrile} \mathrm{under} \mathrm{an} \mathrm{Ar} \mathrm{atmosphere} \mathrm{(WE:} \mathrm{GC,}$ CE: Pt wire, $\mathrm{RE}: \mathrm{Ag} / \mathrm{Ag}^{+}$; scan rate: $100 \mathrm{mV} \mathrm{s}^{-1}$ ).

couple and the latter peak could be assigned to the reduction of $\mathrm{NO}^{\cdot}$ to $\mathrm{NO}^{-}$. Note that a $\mathrm{Ru}(\mathrm{III}) / \mathrm{Ru}(\mathrm{II})$ redox couple was not observed in the potential region between -1.6 and $1.5 \mathrm{~V}$ due to the low HOMO energy level originating from the poor donating ability of the $\mathrm{NO}^{+}$ligand.

Cyclic voltammograms of cis-isomers with various ligands $\mathrm{L}$ are shown in Fig. 7. The redox potentials of a $\mathrm{Ru}(\mathrm{III}) / \mathrm{Ru}(\mathrm{II})$ redox couple for each complex were observed at 0.49, 0.79, and $1.05 \mathrm{~V}$ for $\operatorname{cis}(\mathrm{P}, \mathrm{Cl})-[\mathrm{Ru}(\operatorname{trpy})(\mathrm{Pqn})(\mathrm{Cl})]^{+}($cis- $\mathbf{C l})$, cis-NO $\mathbf{N}_{2}$, and cis-MeCN, respectively. This result indicated the increase in the HOMO

Table 3 UV-Vis absorption data $\left(\lambda_{\max } / \mathrm{nm}\left(10^{-3} \varepsilon / \mathrm{M}^{-1} \mathrm{~cm}^{-1}\right)\right)$ in acetonitrile, infrared data $\left(\mathrm{v} / \mathrm{cm}^{-1}\right)$, and redox potentials $\left(E_{1 / 2} / \mathrm{V}\right.$ s. Fc/Fc $\left.\mathrm{F}^{+}\right)$in acetonitrile for cis-NO and related compounds at room temperature

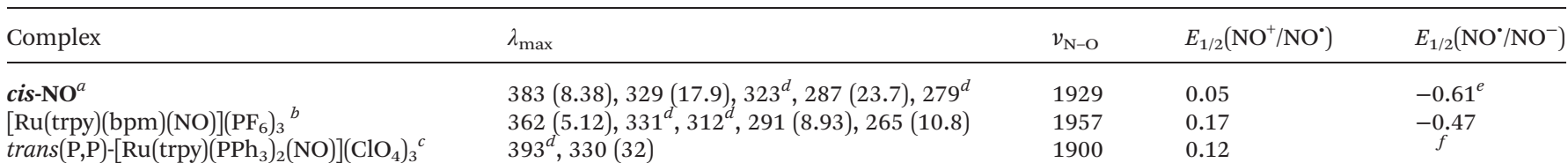

${ }^{a}$ UV-Vis absorption data and redox potentials in ethylene glycol and $\gamma$-butyrolactone, respectively. ${ }^{b}$ Ref. $25 .{ }^{c}$ Ref. $24 .{ }^{d}$ Absorption shoulder. ${ }^{e} E_{\mathrm{pc}}$ value for the irreversible process. ${ }^{f}$ Data not collected. 
Table 4 Redox potentials $\left(\mathrm{V}\right.$ vs. $\mathrm{Fc} / \mathrm{Fc}^{+}$) in acetonitrile for trans $-\mathrm{NO}_{2}$, cis- $-\mathrm{NO}_{2}, \mathrm{PP}-\mathrm{NO}_{2}$, and related compounds at room temperature

\begin{tabular}{|c|c|c|c|c|c|}
\hline \multirow{2}{*}{ Complex } & \multicolumn{3}{|l|}{ Red. } & \multicolumn{2}{|l|}{ Ox. } \\
\hline & $E(1)$ & $E(2)$ & $E(3)$ & $E(1)$ & $E(2)$ \\
\hline trans- $\mathrm{NO}_{2}$ & $-1.77^{b}$ & & $-2.13^{e, g}$ & $0.79^{c, f}$ & $0.97^{g}$ \\
\hline cis $-\mathrm{NO}_{2}$ & -1.70 & -1.99 & - & 0.79 & - \\
\hline PP-NO & $-1.70^{b, e}$ & & $-2.49^{g}$ & $0.95^{c, f}$ & $1.27^{\circ}$ \\
\hline trans-MeCN ${ }^{a}$ & -1.70 & -1.77 & -2.13 & 0.97 & - \\
\hline cis-MeCN ${ }^{a}$ & d & & $d$ & 1.05 & - \\
\hline PP-MeCN ${ }^{a}$ & -1.50 & -1.46 & -2.49 & 1.27 & - \\
\hline
\end{tabular}

${ }^{a}$ Ref. 21. ${ }^{b}$ These reductions induced the dissociation of $\mathrm{NO}_{2}{ }^{-}$and the formation of MeCN-coordinated species. ${ }^{c} \mathrm{NO}_{2}$ was released upon these oxidation processes, and subsequent coordination of MeCN resulted in the formation of corresponding acetonitrile complexes. ${ }^{d}$ cis-MeCN underwent isomerization to trans-MeCN upon reduction. ${ }^{e} E_{\mathrm{pc}}$ values for the irreversible processes. ${ }^{f} E_{\mathrm{pa}}$ values for the irreversible processes. ${ }^{g}$ Redox processes correspond to $\mathrm{MeCN}$ coordinated complexes.
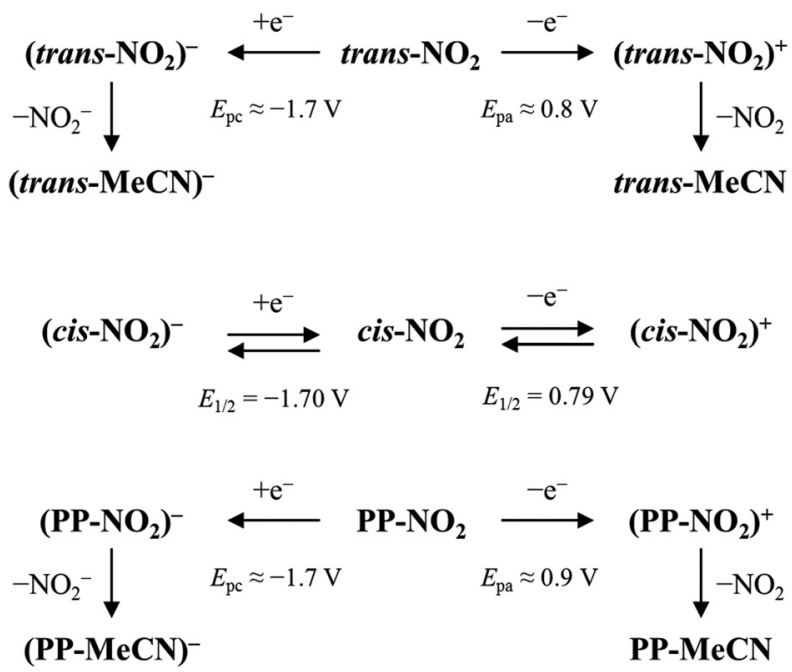

Scheme 3 Electrochemical behaviour of nitrito- $\kappa N$ complexes.

energy level by electron donation from monodentate ligands and was consistent with the UV-vis absorption spectroscopy.

\section{Photostability of a nitrosyl complex}

The photostability of cis-NO was investigated by UV-vis absorption spectroscopy and by using a Sievers nitric oxide analyser (NOA) to evaluate NO release. When a solution of cis-NO in ethylene glycol $(0.05 \mathrm{mM})$ was irradiated at $\lambda_{\text {irr }}=355 \mathrm{~nm}$, the slow spectral changes seen in Fig. 8 were observed. The quantum yields of $\mathrm{NO}$ release, $\Phi_{\mathrm{NO}}$, were quite low, 0.0048 in air saturated solution and 0.003 under helium (ESI Fig. S11 and $\mathrm{S} 12 \dagger)$. These $\Phi_{\mathrm{NO}}$ values are about two orders of magnitude smaller than that measured by Silva et al. for the photolysis of the analogous ruthenium nitrosyl complex, $[\mathrm{Ru}(\mathrm{tpy})(\mathrm{bpy})-$ $(\mathrm{NO})]^{3+}$ (bpy $=2,2^{\prime}$-bipyridine). ${ }^{27}$ Notably, exhaustive photolysis led to a nearly quantitative conversion to a spectrum ana-

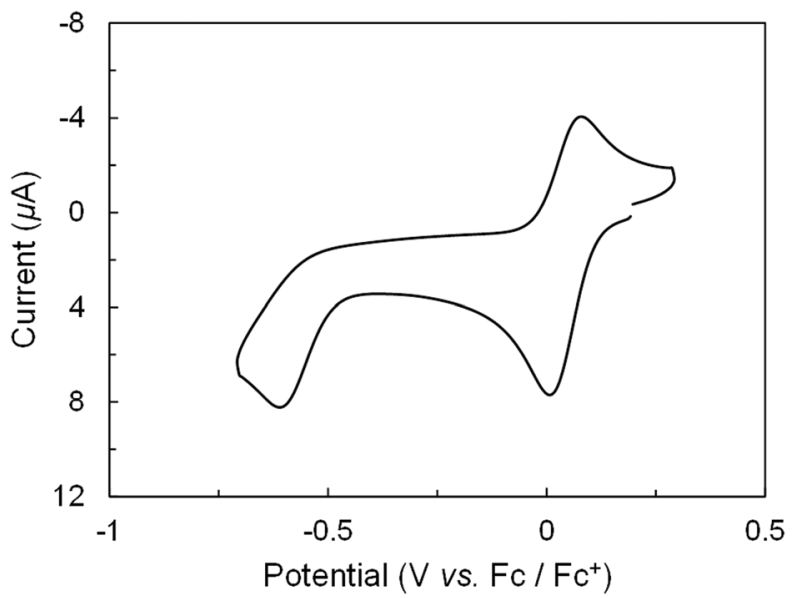

Fig. 6 Cyclic voltammogram of cis-NO $(0.5 \mathrm{mM})$ in $0.1 \mathrm{M}$ TEAP/ $\gamma$-butyrolactone under an Ar atmosphere (WE: GC, CE: Pt wire, RE: Ag/ $\mathrm{Ag}^{+}$; scan rate: $100 \mathrm{mV} \mathrm{s}^{-1}$ ).

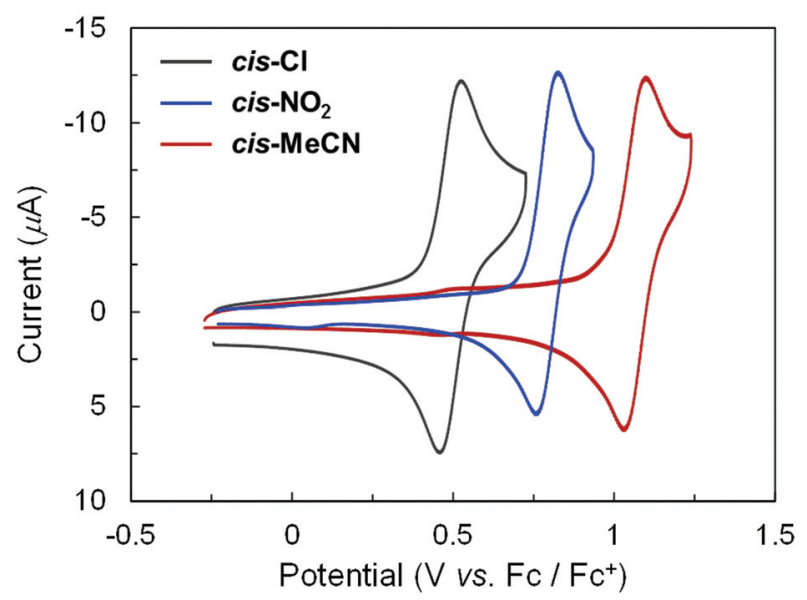

Fig. 7 Cyclic voltammograms of cis- $\mathrm{Cl}$, cis- $\mathrm{NO}_{2}$, and cis-MeCN (0.5 mM) in $0.1 \mathrm{M}$ TEAP/acetonitrile under an Ar atmosphere (WE: GC, $\mathrm{CE}: \mathrm{Pt}$ wire, $\mathrm{RE}: \mathrm{Ag} / \mathrm{Ag}^{+}$; scan rate: $100 \mathrm{mV} \mathrm{s}^{-1}$ ).

logous to that of trans-L ( $\mathrm{L}=$ solvent, see Fig. S13 in the ESI $\dagger$ ), which suggests that the photodissociation of NO and the isomerization of the complex from cis to trans form proceeds in a step-wise manner. The result is consistent with the multi-step spectral change shown in Fig. 8. It should further be noted that a $\mathrm{Ru}(\mathrm{II})$ complex, rather than the $\mathrm{Ru}(\mathrm{III})$ species is obtained upon NO photodissociation from cis-NO (ESI Fig. S13†). There are several possible explanations, one being that the $\mathrm{Ru}(\mathrm{III})$ intermediate is readily reduced by the solvent. Another is that the principal photo-reaction is release of $\mathrm{NO}^{+}$rather than $\mathrm{NO}^{27}$ owing to phosphine stabilization of the low-valent $\mathrm{Ru}(\mathrm{II})$ state. However, this question was not explored in greater detail.

\section{Substitution lability of nitrogen oxide}

The substitution lability of the monodentate ligand $\mathrm{L}$ in the $[\mathrm{Ru}(\mathrm{TL})(\mathrm{BL})(\mathrm{L})]^{n+}$-type complexes is an important factor in 


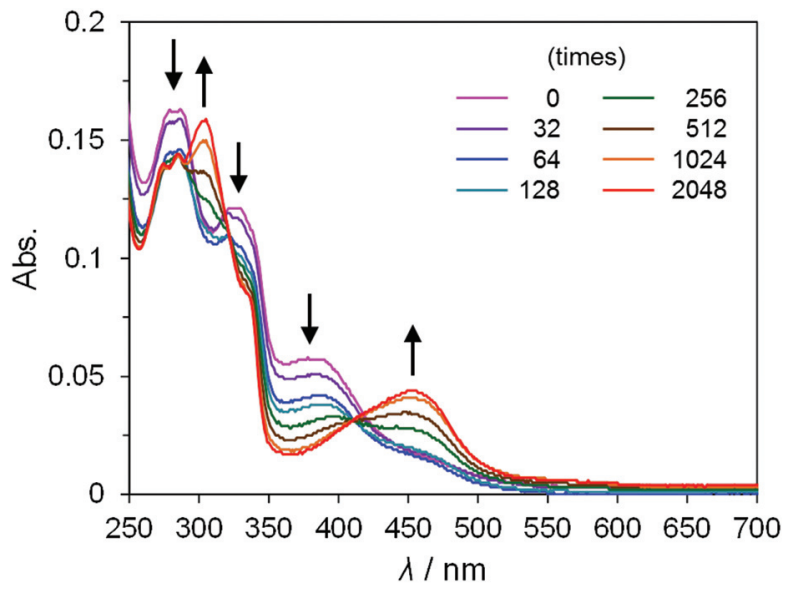

Fig. 8 UV-Vis absorption spectra of cis-NO in ethylene glycol at room temperature during photolysis using a Nd/YAG laser operating at $355 \mathrm{~nm}$. "Times" indicates the number of the laser pulses used to irradiate the sample.

determining the reactivity of the complexes in various catalytic and photo-induced reactions. Several experimental results described above enabled us to discuss in detail the lability of the monodentate ligand in the complexes. First, the reaction of $\boldsymbol{c i s}-\mathrm{NO}_{2}$ with $\mathrm{HPF}_{6}$ afforded the desired cis-NO. However, similar reactions of trans- $\mathbf{N O}_{2}$ and $\mathbf{P P}-\mathbf{N O}_{2}$ resulted in the formation of trans-MeCN and PP-MeCN via the dissociation of a monodentate labile ligand, $\mathrm{N}(\mathrm{O}) \mathrm{OH}$ or $\mathrm{NO}^{+}$(probably the former). Second, UV-vis absorption spectroscopy revealed that the nitrito ligands of trans- $\mathbf{N O}_{2}, \boldsymbol{c i s}-\mathbf{N O}_{2}$, and $\mathbf{P P}-\mathbf{N O}_{2}$ did not dissociate, even in strongly coordinating solvents such as acetonitrile, whereas ligand exchange reactions of trans-MeCN and PP-MeCN easily occurred under analogous conditions (Fig. S14 in the ESI $\dagger$ ). cis-NO was not stable in coordinating solvent and was easily converted to a solvent-coordinated form (Fig. S4 in the ESI†).

The difference in lability of the oxidised and reduced state can also be clarified by the results of the electrochemical measurements. In the one-electron oxidised states, trans- $\mathbf{N O}_{2}$ and $\mathbf{P P}-\mathbf{N O}_{2}$ were labile and were converted to the solventcoordinated forms, trans-MeCN and PP-MeCN, respectively. By contrast, $\boldsymbol{c i s}-\mathrm{NO}_{2}$ was inert during the oxidation process, and a reversible redox wave was observed in the electrochemical measurement. Similarly, in the reduced states, the nitrito ligands of trans- $\mathrm{NO}_{2}$, and $\mathbf{P P}-\mathrm{NO}_{2}$ easily dissociated, although cis- $\mathrm{NO}_{2}$ was stable during the whole electrochemical process. However, this stability of cis- $\mathrm{NO}_{2}$ was quite different from that of cisMeCN: the acetonitrile ligand of $\boldsymbol{c i s - M e C N}$ became labile upon reduction, and the dissociation of the ligand resulted in the iso-

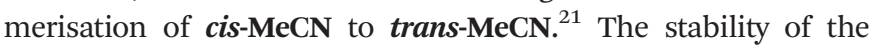
monodentate labile site for each complex is shown in Scheme 4.

The difference in the lability of these complexes can be explained by considering the following factors. First, the $\sigma$-donor character of the phosphine group significantly elongates the bond length between the ruthenium centre and (a) $\mathrm{NO}_{2}$ complex

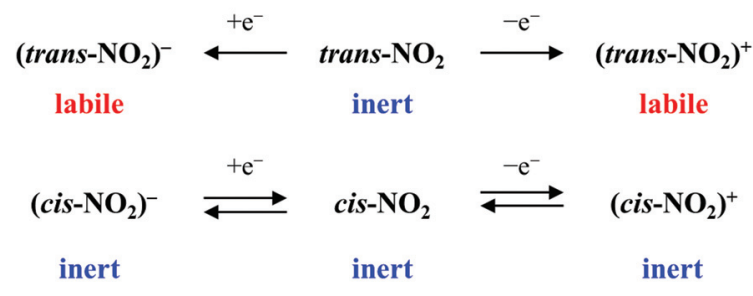

(b) $\mathrm{MeCN}$ complex

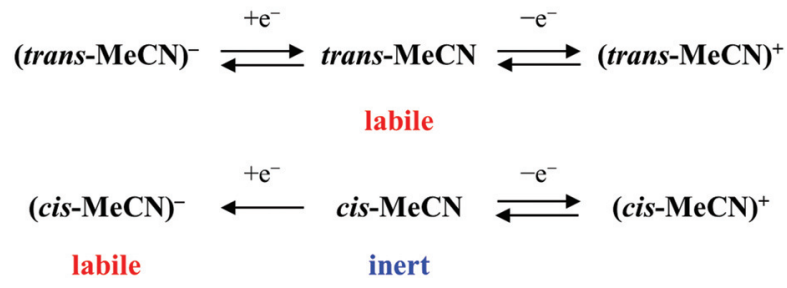

Scheme 4 Changes in lability upon oxidation or reduction.

the ligand trans to the phosphine group. This trans influence of the phosphine group was clearly observed in the X-ray structure for the series of nitrito- $\mathrm{K} N$ complexes; the bond distances between the ruthenium and nitrogen atom of the nitrite ligand are 2.141(3), 2.124(2), and ca. $2.03 \AA$ for trans $-\mathrm{NO}_{2}$, $\mathbf{P P}-\mathrm{NO}_{2}$, and cis- $\mathrm{NO}_{2}$, respectively. Therefore, the trans-isomers and PP complexes exhibited greater lability compared with the corresponding cis-isomers. Second, the electron donation from labile ligands can stabilise $\mathrm{Ru}-\mathrm{L}$ bonds. The donating ability of labile ligands was confirmed by the comparison of the HOMO energy levels obtained from the electrochemical measurements of the cis-isomers and follows the order $\mathrm{NO}_{2}{ }^{-}>\mathrm{MeCN}>\mathrm{NO}^{+}$and was in accordance with the stability of the complexes. Third, oxidation decreases the electron density of the $\mathrm{Ru}$ centre, and the $\pi$ back-donating ability of Ru centres should be weakened. DFT calculations revealed that $\pi$ back-donation from $\mathrm{Ru}$ to the nitrito ligand occurs and stabilises the Ru-L bond (Fig. S6 in the ESI $\dagger$ ). Finally, the reduction of the complexes stabilises the five-coordinated species, as rationalised for the $\mathrm{Ru}(\mathrm{II})-\mathrm{MeCN}$ complexes in our previous report. ${ }^{21}$ The formation of fivecoordinated species in MeCN results in ligand exchange in trans- $\mathrm{NO}_{2}$ and $\mathbf{P P}-\mathrm{NO}_{2}$ or isomerisation of cis-MeCN to transMeCN, whereas no observable chemical process exists in the case of trans-MeCN and PP-MeCN. These results suggest that the (1) number and position of $\mathrm{P}$ atom(s), (2) coordinating ability of the monodentate ligand, and (3) oxidation state of the complexes are all factors in defining the lability of complexes.

\section{Conclusions}

This study describes the syntheses, crystal structures and spectroscopic and electrochemical properties of a series of phos- 
phine-substituted ruthenium(II) polypyridine complexes with nitrogen oxides. Three nitrito- $\mathrm{KN}$ complexes, trans- $\mathrm{NO}_{2}$, cis- $\mathbf{N O}_{2}$, and $\mathbf{P P}-\mathrm{NO}_{2}$, were synthesised by the reaction of the corresponding acetonitrile complex with $\mathrm{NaNO}_{2}$ in an ethanol/water mixed solution, and a nitrosyl complex, cis-NO, was obtained by the reaction of cis- $\mathrm{NO}_{2}$ with $\mathrm{HPF}_{6}$ in acetone. Crystallographic, spectroscopic, and electrochemical analyses for these complexes revealed that the $\sigma$-donating and $\pi$-accepting characters of the phosphine ligands clearly affected the $d \sigma$ and $d \pi$ orbitals of the ruthenium centre, respectively. The investigation of the substitution lability of the monodentate ligand of each complex suggested that the (1) number and position of the phosphine groups, (2) coordinating ability of the monodentate ligand, and (3) oxidation state of the metal centre are all factors in determining the lability of the complex. As a further extension of our studies, investigations on various catalytic and photo-induced reactions of the phosphine-substituted ruthenium(II) polypyridine complexes are in progress in our laboratories.

\section{Experimental}

\section{Materials}

$\mathrm{NaNO}_{2}$ was purchased from Kanto Chemical Co., Inc. $\mathrm{NH}_{4} \mathrm{PF}_{6}$ and $\mathrm{HPF}_{6}$ were purchased from Wako Pure Chemical Industries, Ltd. All solvents and reagents were of the highest quality available and were used as received. $\operatorname{cis}(\mathrm{P}, \mathrm{Cl})-[\mathrm{Ru}(\mathrm{trpy})-$ (Pqn)Cl] $\mathrm{PF}_{6}$ (cis-Cl), trans( $\left.\mathrm{P}, \mathrm{MeCN}\right)-$ and $\operatorname{cis}(\mathrm{P}, \mathrm{MeCN})-[\mathrm{Ru}(\mathrm{trpy})-$ $(\mathrm{Pqn})(\mathrm{MeCN})]\left(\mathrm{PF}_{6}\right)_{2}$ (trans-MeCN and cis-MeCN), and $[\mathrm{Ru}(\operatorname{trpy})-$ (dppbz)(MeCN)]( $\left.\mathrm{PF}_{6}\right)_{2}$ (PP-MeCN) were prepared following methods found in the literature. ${ }^{21}$

\section{Measurements}

${ }^{1} \mathrm{H}$ and ${ }^{31} \mathrm{P}\left\{{ }^{1} \mathrm{H}\right\}$ NMR spectra were recorded at room temperature on a JEOL JNM-LA500 spectrometer using tetramethylsilane as an internal reference for the ${ }^{1} \mathrm{H}$ NMR spectra and phosphoric acid as an external reference for the ${ }^{31} \mathrm{P}\left\{{ }^{1} \mathrm{H}\right\}$ NMR spectra. UV-vis absorption spectra were obtained on a Shimadzu UV-2450SIM spectrophotometer at room temperature. Elemental analyses were carried out on a Yanagimoto MT-5 elemental analyser. Infrared data were obtained using a Perkin-Elmer Spectrum 100 FT-IR spectrometer. ESI-TOF mass spectra were recorded on a JEOL JMS-T100LC mass spectrometer. All the ESI-TOF mass spectrometric measurements were recorded in the positive ion mode at a cone voltage of $20 \mathrm{~V}$. Typically, each sample solution was introduced in the spectrometer at a flow rate of $10 \mathrm{~mL} \mathrm{~min}{ }^{-1}$ using a syringe pump. Cyclic voltammograms were measured at room temperature on a BAS ALS Model 650DKMP electrochemical analyser in acetonitrile ([complex] $=0.5 \mathrm{mM} ; 0.1 \mathrm{M}$ tetraethylammonium perchlorate (TEAP)). A glassy carbon disk, platinum wire, and $\mathrm{Ag} / \mathrm{Ag}^{+}$electrode $\left(\mathrm{Ag} / 0.01 \quad \mathrm{M} \quad \mathrm{AgNO}_{3}\right)$ were used as the working, auxiliary, and reference electrodes, respectively. The redox potentials of the samples were calibrated against the redox signal for the ferrocene/ ferrocenium $\left(\mathrm{Fc} / \mathrm{Fc}^{+}\right)$couple. The photochemical experiments shown in Fig. 8 were made using a photolysis apparatus consisting of a LS-2134UTF Nd/YAG laser (Tokyo Instruments, INC.) with excitation provided by the third harmonic at $\lambda=355 \mathrm{~nm}$. The pulse width was $5 \mathrm{~ns}$, the beam diameter incident on the sample was $6 \mathrm{~mm}$, and the repetition rate was $5 \mathrm{~Hz}$.

\section{Synthetic procedures}

Synthesis of trans $\left(\mathrm{P}, \mathrm{NO}_{2}\right)-\left[\mathrm{Ru}(\operatorname{trpy})(\mathrm{Pqn})\left(\mathrm{NO}_{2}\right)\right] \mathrm{PF}_{6}$ (trans$\left.\mathbf{N O}_{2}\right)$. A mixture of trans-MeCN $(26.8 \mathrm{mg}, 0.0252 \mathrm{mmol})$ and $\mathrm{NaNO}_{2}(38.8 \mathrm{mg}, 0.562 \mathrm{mmol})$ in ethanol $\left(4 \mathrm{~cm}^{3}\right) /$ water $\left(4 \mathrm{~cm}^{3}\right)$ was heated at $100{ }^{\circ} \mathrm{C}$ for 3 hours and then cooled to room temperature. Acetonitrile $\left(2 \mathrm{~cm}^{3}\right)$ and a $\mathrm{NH}_{4} \mathrm{PF}_{6}(188.4 \mathrm{mg}$, $1.16 \mathrm{mmol}$ )/water $\left(2 \mathrm{~cm}^{3}\right)$ solution was added to the abovementioned solution. The resulting red solution was concentrated to $c a .5 \mathrm{~cm}^{3}$ under reduced pressure. The red product was collected by filtration and washed with water and diethyl ether. Yield $19.1 \mathrm{mg}(0.0216 \mathrm{mmol}, 86 \%)$. Single red crystals suitable for X-ray crystallography were grown by the slow diffusion of diethyl ether into a mixture of methanol and a few drops of acetonitrile solution of trans-NO $\mathrm{N}_{2}$. ESI-TOF MS (positive ion, acetonitrile): $m / z 694$ ([Ru(trpy)(Pqn) $\left.\left.\left(\mathrm{NO}_{2}\right)\right]^{+}\right) .{ }^{1} \mathrm{H}$ NMR $\left(\mathrm{CD}_{3} \mathrm{CN}\right): \delta 6.56(\mathrm{t}, 2 \mathrm{H}, J=9.0 \mathrm{~Hz}), 6.98(\mathrm{t}, 4 \mathrm{H}, J=7.0 \mathrm{~Hz}), 7.14$ $(\mathrm{t}, 2 \mathrm{H}, J=7.0 \mathrm{~Hz}), 7.21(\mathrm{t}, 2 \mathrm{H}, J=8.0 \mathrm{~Hz}), 7.65(\mathrm{~d}, 2 \mathrm{H}, J=5.0$ $\mathrm{Hz}), 7.80(\mathrm{t}, 2 \mathrm{H}, J=8.0 \mathrm{~Hz}), 7.91(\mathrm{~m}, 3 \mathrm{H}), 8.03(\mathrm{~d}, 2 \mathrm{H}, J=$ $8.0 \mathrm{~Hz}$ ), 8.09 (t, $1 \mathrm{H}, J=7.5 \mathrm{~Hz}), 8.23(\mathrm{~d}, 2 \mathrm{H}, J=8.0 \mathrm{~Hz}), 8.46$ $(\mathrm{d}, 1 \mathrm{H}, J=7.0 \mathrm{~Hz}), 8.75(\mathrm{~d}, 1 \mathrm{H}, J=8.0 \mathrm{~Hz}), 9.93(\mathrm{~d}, 1 \mathrm{H}, J=$ $5.0 \mathrm{~Hz}) .{ }^{31} \mathrm{P}\left\{{ }^{1} \mathrm{H}\right\}$ NMR $\left(\mathrm{CD}_{3} \mathrm{CN}\right): \delta 53.10(\mathrm{~s}) . \quad$ FT-IR: $\nu_{\mathrm{s}}\left(\mathrm{NO}_{2}\right)$ 1304, $\nu_{\text {as }}\left(\mathrm{NO}_{2}\right) 1349 \mathrm{~cm}^{-1}$. Anal. Found: C, 48.50; H, 3.59; $\mathrm{N}$, 8.22. Calcd for $\mathrm{C}_{36} \mathrm{H}_{32} \mathrm{~F}_{6} \mathrm{~N}_{5} \mathrm{O}_{4.5} \mathrm{P}_{2} \mathrm{Ru}$ (trans $-\mathrm{NO}_{2} \cdot 2.5 \mathrm{H}_{2} \mathrm{O}$ ): C, 48.93; H, 3.65; N, 7.93.

Synthesis of $\operatorname{cis}\left(\mathbf{P}, \mathrm{NO}_{2}\right)-\left[\mathrm{Ru}(\operatorname{trpy})(\mathrm{Pqn})\left(\mathrm{NO}_{2}\right)\right] \mathrm{PF}_{6} \quad\left(\right.$ cis- $\left.-\mathrm{NO}_{2}\right)$. This complex was prepared from cis-MeCN $(26.0 \mathrm{mg}$, $0.0250 \mathrm{mmol}$ ) instead of trans-MeCN by a method similar to that for trans-NO $\mathrm{NO}_{2}$. Yield $19.5 \mathrm{mg}(0.0221 \mathrm{mmol}, 88 \%)$. ESI-TOF MS (positive ion, acetonitrile): $m / z 694$ ([Ru(trpy)(Pqn) $\left.\left.\left(\mathrm{NO}_{2}\right)\right]^{+}\right) .{ }^{1} \mathrm{H}$ NMR $\left(\mathrm{CD}_{3} \mathrm{CN}\right): \delta 6.81(\mathrm{t}, 2 \mathrm{H}, J=6.5 \mathrm{~Hz}), 7.06$ $(\mathrm{m}, 1 \mathrm{H}), 7.41(\mathrm{~d}, 2 \mathrm{H}, J=5.5 \mathrm{~Hz}), 7.52(\mathrm{~m}, 4 \mathrm{H}), 7.63(\mathrm{t}, 2 \mathrm{H}, J=$ $7.5 \mathrm{~Hz}), 7.73(\mathrm{~m}, 4 \mathrm{H}), 7.84(\mathrm{t}, 2 \mathrm{H}, J=8.0 \mathrm{~Hz}), 7.92(\mathrm{~d}, 1 \mathrm{H}, J=$ $5.5 \mathrm{~Hz}), 7.97(\mathrm{t}, 1 \mathrm{H}, J=7.5 \mathrm{~Hz}), 8.18(\mathrm{~d}, 1 \mathrm{H}, J=8.0 \mathrm{~Hz}), 8.23$ $(\mathrm{d}, 1 \mathrm{H}, J=8.0 \mathrm{~Hz}), 8.36(\mathrm{~m}, 3 \mathrm{H}), 8.55(\mathrm{~d}, 2 \mathrm{H}, J=8.0 \mathrm{~Hz}) 8.78$ (t, $1 \mathrm{H}, J=8.0 \mathrm{~Hz}) \cdot{ }^{31} \mathrm{P}\left\{{ }^{1} \mathrm{H}\right\}$ NMR $\left(\mathrm{CD}_{3} \mathrm{CN}\right): \delta 54.06$ (s). FT-IR: $\nu_{\mathrm{s}}\left(\mathrm{NO}_{2}\right)$ 1286, $\nu_{\text {as }}\left(\mathrm{NO}_{2}\right) 1339 \mathrm{~cm}^{-1}$. Anal. Found: C, 50.38; $\mathrm{H}, 3.44 ; \mathrm{N}$, 8.19. Calcd for $\mathrm{C}_{36} \mathrm{H}_{29} \mathrm{~F}_{6} \mathrm{~N}_{5} \mathrm{O}_{3} \mathrm{P}_{2} \mathrm{Ru}\left(\right.$ cis- $\left.-\mathrm{NO}_{2} \cdot \mathrm{H}_{2} \mathrm{O}\right)$ : C, 50.47; H, 3.41; N, 8.18.

Synthesis of $\operatorname{cis}\left(\mathrm{P}, \mathrm{NO}_{2}\right)-\left[\mathrm{Ru}(\operatorname{trpy})(\mathrm{Pqn})\left(\mathrm{NO}_{2}\right)\right] \mathrm{BPh}_{4}\left(\right.$ cis- $\left.\mathrm{NO}_{2}{ }^{\prime}\right)$. This complex was prepared by a method similar to that for cis- $\mathrm{NO}_{2}$ with an excess of $\mathrm{NaBPh}_{4}$ instead of $\mathrm{NH}_{4} \mathrm{PF}_{6}$. The product was recrystallised from dichloromethane and a small amount of acetonitrile/diethyl ether to afford orange-red crystals of $\boldsymbol{c i s}-\mathrm{NO}_{2}{ }^{\prime}$. Anal. Found: C, 70.54; H, 4.72; N, 6.92. Calcd for $\mathrm{C}_{60} \mathrm{H}_{48} \mathrm{BN}_{5} \mathrm{O}_{2.5} \mathrm{PRu}\left(\right.$ cis- $\mathrm{NO}_{2}{ }^{\prime} \cdot 0.5 \mathrm{H}_{2} \mathrm{O}$ ): C, 70.52; $\mathrm{H}$, $4.73 ; \mathrm{N}, 6.85$. 
Synthesis of $\operatorname{cis}(\mathrm{P}, \mathrm{NO})-[\mathrm{Ru}(\mathrm{trpy})(\mathrm{Pqn})(\mathrm{NO})]\left(\mathrm{PF}_{6}\right)_{3} \quad$ (cis-NO). cis- $\mathrm{NO}_{2}(22.4 \mathrm{mg}, 0.0261 \mathrm{mmol})$ was dissolved in acetone $\left(1 \mathrm{~cm}^{3}\right)$. An excess of $60 \% \mathrm{HPF}_{6}$ acid solution was added dropwise until the solution changed colour from red to yellow with the shielding of light in an ice-water bath. The resulting yellow solution was concentrated under reduced pressure, and $10 \mathrm{~cm}^{3}$ of diethyl ether was added to precipitate the product. Yield $27.4 \mathrm{mg}(0.0223 \mathrm{mmol}, 85 \%) .{ }^{1} \mathrm{H}$ NMR (acetone- $\left.d_{6}\right): \delta$ $7.47(\mathrm{t}, 2 \mathrm{H}, J=7.0 \mathrm{~Hz}), 7.66(\mathrm{~m}, 1 \mathrm{H}), 7.80(\mathrm{~d}, 2 \mathrm{H}, J=6.0 \mathrm{~Hz})$, $7.86(\mathrm{~m}, 4 \mathrm{H}), 8.01(\mathrm{t}, 2 \mathrm{H}, J=7.5 \mathrm{~Hz}), 8.12(\mathrm{dd}, 4 \mathrm{H}, J=7.5,13.0$ $\mathrm{Hz}), 8.42(\mathrm{t}, 1 \mathrm{H}, J=7.5 \mathrm{~Hz}), 8.49(\mathrm{~m}, 2 \mathrm{H}), 8.55(\mathrm{~m}, 1 \mathrm{H}), 8.80(\mathrm{~d}$, $1 \mathrm{H}, J=8.0 \mathrm{~Hz}), 9.01(\mathrm{~m}, 3 \mathrm{H}), 9.10(\mathrm{~m}, 1 \mathrm{H}), 9.22(\mathrm{~m}, 3 \mathrm{H}) .{ }^{31} \mathrm{P}$ $\left\{{ }^{1} \mathrm{H}\right\}$ NMR (acetone- $d_{6}$ ): $\delta 54.23$ (s). FT-IR: $\nu_{\mathrm{s}}(\mathrm{NO}) 1929 \mathrm{~cm}^{-1}$. Anal. Found: $\mathrm{C}, \quad 35.03 ; \mathrm{H}, 2.95 ; \mathrm{N}, 5.59$. Calcd for $\mathrm{C}_{36} \mathrm{H}_{40} \mathrm{~F}_{18} \mathrm{~N}_{5} \mathrm{O}_{7.5} \mathrm{P}_{4} \mathrm{Ru}\left(\right.$ cis-NO-6.5 $\left.\mathrm{H}_{2} \mathrm{O}\right)$ ): C, 35.16; H, 3.28; N, 5.70.

Synthesis of $\left[\mathrm{Ru}(\mathrm{trpy})(\mathrm{dppbz})\left(\mathrm{NO}_{2}\right)\right] \mathbf{P F}_{\mathbf{6}} \quad\left(\mathbf{P P}^{\mathrm{N}} \mathrm{NO}_{2}\right)$. This complex was prepared from PP-MeCN $(31.5 \mathrm{mg}, 0.0263 \mathrm{mmol})$ instead of trans-MeCN by a method similar to that for trans$\mathbf{N O}_{2}$. Yield $22.9 \mathrm{mg}(0.0227 \mathrm{mmol}, 86 \%)$. Single orange crystals suitable for X-ray crystallography were grown through the slow diffusion of diethyl ether into a mixture of methanol and a few drops of acetonitrile solution of PP-NO $\mathbf{N}_{2}$. ESI-TOF MS (positive ion, acetonitrile): $m / z 827$ ([Ru(trpy)(dppbz) $\left.\left.\left(\mathrm{NO}_{2}\right)\right]^{+}\right) .{ }^{1} \mathrm{H}$ NMR $\left(\mathrm{CD}_{3} \mathrm{CN}\right): \delta 6.50(\mathrm{~m}, 4 \mathrm{H}), 6.78(\mathrm{~m}, 2 \mathrm{H}), 6.88(\mathrm{~m}, 4 \mathrm{H}), 7.08$ $(\mathrm{d}, 2 \mathrm{H}, J=5.5 \mathrm{~Hz}), 7.17(\mathrm{~m}, 2 \mathrm{H}), 7.45(\mathrm{t}, 4 \mathrm{H}, J=7.5 \mathrm{~Hz}), 7.61$ $(\mathrm{m}, 7 \mathrm{H}), 7.77(\mathrm{~m}, 3 \mathrm{H}), 7.87(\mathrm{t}, 1 \mathrm{H}, J=7.5 \mathrm{~Hz}), 8.03(\mathrm{~d}, 2 \mathrm{H}, J=$ $8.0 \mathrm{~Hz}), 8.23(\mathrm{~m}, 3 \mathrm{H}), 8.39(\mathrm{t}, 1 \mathrm{H}, J=7.5 \mathrm{~Hz}) .{ }^{31} \mathrm{P}\left\{{ }^{1} \mathrm{H}\right\} \mathrm{NMR}$ $\left(\mathrm{CD}_{3} \mathrm{CN}\right): \delta 62.65\left(\mathrm{~d},{ }^{2} J_{\mathrm{P}-\mathrm{P}}=14.2 \mathrm{~Hz}\right), 68.59\left(\mathrm{~d},{ }^{2} J_{\mathrm{P}-\mathrm{P}}=14.2 \mathrm{~Hz}\right)$. FT-IR: $\nu_{\mathrm{s}}\left(\mathrm{NO}_{2}\right)$ 1311, $\nu_{\text {as }}\left(\mathrm{NO}_{2}\right) 1354 \mathrm{~cm}^{-1}$. Anal. Found: C, 53.62; H, 4.05; N, 5.46. Calcd for $\mathrm{C}_{45} \mathrm{H}_{39} \mathrm{~F}_{6} \mathrm{~N}_{4} \mathrm{O}_{4} \mathrm{P}_{3} \mathrm{Ru}$ $\left(\mathbf{P P}-\mathrm{NO}_{2} \cdot 2 \mathrm{H}_{2} \mathrm{O}\right)$ : C, 53.63; H, 3.90; N, 5.56.

\section{X-ray crystallography}

The X-ray data collection and processing was performed on a Kappa APEX II CCDC diffractometer by using graphite-mono-

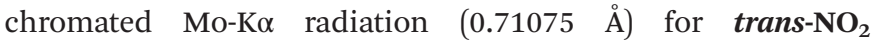
and $\mathbf{P P}-\mathrm{NO}_{2}$. Single-crystal X-ray diffraction measurement of cis- $\mathrm{NO}_{2}{ }^{\prime}$ was performed with a RAXIS-RAPID Imaging Plate diffractometer equipped with confocal monochromated Mo-K $\alpha(0.71075 \AA)$ radiation, and the data were processed using RAPID-AUTO (Rigaku). The structure was solved by the direct methods using SIR- $92^{28}$ and refined on $F^{2}$ with the full-matrix least squares technique using SHELXL-2014. ${ }^{29}$ All non-hydrogen atoms were refined anisotropically. Molecular graphics were generated using ORTEP-3 for Windows $^{30}$ and POV-RAY. ${ }^{31}$ A summary of the crystallographic data and structure refinement parameters is given in Table 1.

The crystallographic data have been deposited at the Cambridge Crystallographic Data Centre: deposition numbers CCDC 1040452, 1040453, and 1040454 for trans- $\mathbf{N O}_{2}$, cis- $\mathbf{N O}_{2}{ }^{\prime}$, and $\mathbf{P P}-\mathrm{NO}_{2}$, respectively.

\section{DFT calculations}

Calculations were performed using the DFT method implemented in the Gaussian 09 package. ${ }^{32}$ The structures were fully optimised using the hybrid B3LYP method, which uses Becke's three-parameter exchange functional ${ }^{33}$ with the correlation energy functional of Lee, Yang, and Parr. ${ }^{34}$ All calculations were performed using the standard double- $\zeta$ type LANL2DZ basis set ${ }^{35 a-c}$ or SDD basis set ${ }^{35 d}$ implemented in Gaussian 09, without adding any extra polarisation or diffuse functions. The LANL2DZ basis set also uses a relativistic effective core potential (RECP) for the Ru atom to account for the scalar relativistic effects of the inner 28 core electrons ([Ar] $\left.3 \mathrm{~d}^{10}\right)$. All calculations were performed using the polarisable continuum model (PCM) ${ }^{36}$ to compute the structures in acetonitrile media. All stationary points were characterised as minima of the potential energy surface by their harmonic vibrational frequencies. The free energies at $298 \mathrm{~K}$ and $1 \mathrm{~atm}$ were obtained through thermochemical analysis of the frequency calculation using the thermal correction to Gibbs free energy as implemented in Gaussian 09. The excited states were calculated using the TDDFT $^{37}$ method within the TammDancoff approximation as implemented in Gaussian 09. These calculations employ the hybrid B3LYP functional along with the basis sets described above. A minimum of 100 excited states was computed in each calculation. To obtain the simulated spectrum of each species, transition energies and oscillator strengths were interpolated by a Gaussian convolution with a common $\sigma$ value of $0.2 \mathrm{eV}$.

\section{Quantum yield measurements}

Nitric oxide was detected and analysed using a GE Sievers model 280i nitric oxide analyser (NOA). ${ }^{38}$ Known volumes of the gases from the solution headspace were injected into the NOA purge vessel, and these gases were entrained to the detector using helium or medical grade air. The NO present in the sample was quantified using a calibration curve generated from the reaction of $\mathrm{NaNO}_{2}$ with acidic KI. Chemical actinometry was performed with ferric oxalate solutions. ${ }^{39}$ The photolysis source was the output from a $200 \mathrm{~W}$ high-pressure mercury lamp passed through an IR filter and collimated with lenses. An appropriate interference filter was used to select the desired $\lambda_{\text {irr }}$. A shutter shielded the sample from the arc lamp. A sample of a known volume in a $1 \mathrm{~cm}$ square cuvette with a magnetic stirring bar was irradiated for determined time periods. ${ }^{40}$ The NO quantum yields $\left(\Phi_{\mathrm{NO}}\right)$ were calculated based on the nitric oxide release measured using the NOA.

\section{Acknowledgements}

This work was supported by a Grant-in-Aid for Young Scientists (A) (No. 25708011) (to S.M.), a Grant-in-Aid for Challenging Exploratory Research (No. 26620160) (to S.M.), and a Grant-inAid for Young Scientists (A) (No. 15H05480) (to M.K) from the Japan Society for the Promotion of Science. This work was also supported by a Grant-in-Aid for Scientific Research on Innovative Areas "AnApple" (No. 25107526). Studies at UCSB were supported by a US National Foundation Grant (CHE-1058794 and CHE-1405062). We thank Dr Guang Wu of UCSB for the 
X-ray diffraction studies and Dr John Garcia of UCSB for confirming photochemical results.

\section{Notes and references}

1 (a) N. Sutin, J. Photochem., 1979, 10, 19-40; (b) K. Kalyanasundaram, Coord. Chem. Rev., 1982, 46, 159244; (c) E. S. Dodsworth and A. B. P. Lever, Chem. Phys. Lett., 1986, 124, 152-158; (d) A. Juris, V. Balzani, F. Barigelletti, S. Campagna, P. Belser and A. von Zelewsky, Coord. Chem. Rev., 1988, 84, 85-277; (e) A. B. P. Lever, Inorg. Chem., 1990, 29, 1271-1285; ( $f$ ) V. Balzani and A. Juris, Coord. Chem. Rev., 2001, 211, 97-115; (g) D. W. Thompson, J. F. Wishart, B. S. Brunschwig and N. Sutin, J. Phys. Chem. A, 2001, 105, 8117-8122; (h) S. Campagna, F. Puntoriero, F. Nastasi, G. Bergamini and V. Balzani, Top. Curr. Chem., 2007, 280, 117-214; (i) T. P. Yoon, M. A. Ischay and J. Du, Nat. Chem., 2010, 2, 527-532; (j) Q. Sun, S. MosqueraVazquez, Y. Suffren, J. Hankache, N. Amstutz, L. M. L. Daku, E. Vauthey and A. Hauser, Coord. Chem. Rev., 2015, 282-283, 87-99.

2 (a) C. D. Clark and M. Z. Hoffman, Coord. Chem. Rev., 1997, 159, 359-373; (b) L. De Cola and P. Belser, Coord. Chem. Rev., 1998, 177, 301-346; (c) M. D. Ward and F. Barigelletti, Coord. Chem. Rev., 2001, 216-217, 127-154; (d) M. H. V. Huynh, D. M. Dattelbaum and T. J. Meyer, Coord. Chem. Rev., 2005, 249, 457-483; H. Kon, K. Tsuge, T. Imamura, Y. Sasaki, S. Ishizaka, N. Kitamura and M. Kato, Dalton Trans., 2008, 1541-1543; (e) A. LavieCambot, C. Lincheneau, M. Cantuel, Y. Leydet and N. D. McClenaghan, Chem. Soc. Rev., 2010, 39, 506-515; (f) O. Filevich, B. García-Acosta and R. Etchenique, Photochem. Photobiol. Sci., 2012, 11, 843-847.

3 (a) F. G. Gao and A. J. Bard, J. Am. Chem. Soc., 2000, 122, 7426-7427; (b) J. N. Demas and B. A. DeGraff, Coord. Chem. Rev., 2001, 211, 317-351; (c) P. D. Beer and E. J. Hayes, Coord. Chem. Rev., 2003, 240, 167-189; (d) R. MartinezMáñez and F. Sancenón, Chem. Rev., 2003, 103, 4419-4476; (e) A. S. Polo, M. K. Itokazu and N. Y. M. Iha, Coord. Chem. Rev., 2004, 248, 1343-1361; $(f)$ M. S. Vickers, K. S. Martindale and P. D. Beer, J. Mater. Chem., 2005, 15, 2784-2790; (g) N. Haddour, J. Chauvin, C. Gondran and S. Cosnier, J. Am. Chem. Soc., 2006, 128, 9693-9698; (h) H. Wei and E. Wang, Trends Anal. Chem., 2008, 27, 447-459; (i) J. L. Delaney, C. F. Hogan, J. Tian and W. Shen, Anal. Chem., 2011, 83, 1300-1306.

4 (a) G. J. Wilson, A. Launikonis, W. H. F. Sasse and A. W.-H. Mau, J. Phys. Chem. A, 1997, 101, 4860-4866; (b) J. A. Simon, S. L. Curry, R. H. Schmehl, T. R. Schatz, P. Piotrowiak, X. Jin and R. P. Thummel, J. Am. Chem. Soc., 1997, 119, 11012-11022; (c) A. D. Guerzo, S. Leroy, F. Fages and R. H. Schmehl, Inorg. Chem., 2002, 41, 359-366; (d) D. S. Tyson, C. R. Luman, X. Zhou and F. N. Castellano, Inorg. Chem., 2001, 40, 4063-4071; (e) S. Bernhard, J. A. Barron, P. L. Houston, H. D. Abruña, J. L. Ruglovksy,
X. Gao and G. G. Malliaras, J. Am. Chem. Soc., 2002, 128, 9693-9698; (f) S. Welter, K. Brunner, J. W. Hofstraat and L. D. Cola, Nature, 2003, 421, 54-57; (g) H. Shahroosvand, P. Abbasi, A. Faghih, E. Mohajerani, M. Janghouri and M. Mahmoudi, RSC Adv., 2014, 4, 1150-1154.

5 (a) J. K. Barton, Science, 1986, 233, 727-734; (b) C. Turro, S. H. Bossmann, Y. Jenkins, J. K. Barton and N. J. Turro, J. Am. Chem. Soc., 1995, 117, 9026-9032; (c) H. B. Gray and J. R. Winkler, Annu. Rev. Biochem., 1996, 65, 537-561; (d) A. D. Guerzo and A. K.-D. Mesmaeker, Inorg. Chem., 2002, 41, 938-945; (e) S. Le Gac, M. Foucart, P. Gerbaux, E. Defrancq, C. Moucheron and A. Kirsch-De Mesmaeker, Dalton Trans., 2010, 39, 9672-9683; $(f)$ H. Song, J. T. Kaiser and J. K. Barton, Nat. Chem., 2012, 4, 615-620; (g) H. Niyazi, J. P. Hall, K. O’Sullivan, G. Winter, T. Sorensen, J. M. Kelly and C. J. Cardin, Nat. Chem., 2012, 4, 621-628; (h) A. C. Komor and J. K. Barton, Chem. Commun., 2013, 49, 3617-3630.

6 (a) T. J. Meyer and M. H. V. Huynh, Inorg. Chem., 2003, 42, 8140-8160; (b) E. Masllorens, M. Rodriguez, I. Romero, A. Roglans, T. Parella, J. Benet-Buchholz, M. Poyatos and A. Llobet, J. Am. Chem. Soc., 2006, 128, 5306-5307; (c) Y. Shiota, J. M. Herrera, G. Juhász, T. Abe, S. Ohzu, T. Ishizuka, T. Kojima and K. Yoshizawa, Inorg. Chem., 2011, 50, 6200-6209; (d) T. Kojima, K. Nakayama, K. Ikemura, T. Ogura and S. Fukuzumi, J. Am. Chem. Soc., 2011, 133, 11692-11700; (e) Z. Hu, H. Du, W.-L. Man, C.-F. Leung, H. Liang and T.-C. Lau, Chem. Commun., 2012, 48, 1102-1104; (f) Z. Hu, L. Ma, J. Xie, H. Du, W. W. Y. Lam and T.-C. Lau, New J. Chem., 2013, 37, 1707-1710.

7 (a) J. J. Concepcion, J. W. Jurss, J. L. Templeton and T. J. Meyer, J. Am. Chem. Soc., 2008, 130, 16462-16463; (b) H.-W. Tseng, R. Zong, J. T. Muckerman and R. P. Thummel, Inorg. Chem., 2008, 47, 11763-11773; (c) S. Masaoka and K. Sakai, Chem. Lett., 2009, 38, 182-183; (d) M. Yoshida, S. Masaoka and K. Sakai, Chem. Lett., 2009, 38, 702-703; (e) S. Romain, L. Vigara and A. Llobet, Acc. Chem. Res., 2009, 42, 1944-1953; (f) J. J. Concepcion, J. W. Jurss, M. K. Brennaman, P. G. Hoertz, A. O. T. Patrocinio, N. Y. Murakami Iha, J. L. Templeton and T. J. Meyer, Acc. Chem. Res., 2009, 42, 1954-1965; (g) L. Duan, L. Tong, Y. Xu and L. Sun, Energy Environ. Sci., 2011, 4, 3296-3313; (h) D. J. Wasylenko, R. D. Palmer and C. P. Berlinguette, Chem. Commun., 2013, 49, 218-227; (i) M. D. Kärkäs, O. Verho, E. V. Johnston and B. Åkermark, Chem. Rev., 2014, 114, 11863-12001.

8 (a) H. Yamazaki, T. Hakamata, M. Komi and M. Yagi, J. Am. Chem. Soc., 2011, 133, 8846-8849; (b) J. L. Boyer, D. E. Polyansky, D. J. Szalda, R. Zong, R. P. Thummel and E. Fujita, Angew. Chem., Int. Ed., 2011, 50, 12600-12604; (c) S. K. Padhi, R. Fukuda, M. Ehara and K. Tanaka, Inorg. Chem., 2012, 51, 5386-5392; (d) M. Hirahara, M. Z. Ertem, M. Komi, H. Yamazaki, C. J. Cramer and M. Yagi, Inorg. Chem., 2013, 52, 6354-6364.

9 (a) K. Tanaka and D. Ooyama, Coord. Chem. Rev., 2002, 226, 211-218; (b) J.-M. Savéant, Chem. Rev., 2008, 108, 
2348-2378; (c) Y. Tsukahara, T. Wada and K. Tanaka, Chem. Lett., 2010, 39, 1134-1135; (d) K. Kobayashi, T. Kikuchi, S. Kitagawa and K. Tanaka, Angew. Chem., Int. Ed., 2014, 52, 1-6.

10 (a) Z. Chen, C. Chen, D. R. Weinberg, P. Kang, J. J. Concepcion, D. P. Harrison, M. S. Brookhart and T. J. Meyer, Chem. Commun., 2011, 47, 12607-12609; (b) Z. Chen, J. J. Concepcion, M. K. Brennaman, P. Kang, M. R. Norris, P. G. Hoertz and T. J. Meyer, Proc. Natl. Acad. Sci. U. S. A., 2012, 109, 15606-15611; (c) Z. Chen, P. Kang, M.-T. Zhang and T. J. Meyer, Chem. Commun., 2014, 50, 335-337; (d) P. Kang, Z. Chen, A. Nayak, S. Zhang and T. J. Meyer, Energy Environ. Sci., 2014, 7, 40074012.

11 (a) A. Kobayashi, R. Takatori, I. Kikuchi, H. Konno, K. Sakamoto and O. Ishitani, Organometallics, 2001, 20, 3361-3363; (b) A. Kobayashi, H. Konno, K. Sakamoto, A. Sekine, Y. Ohashi, M. Iida and O. Ishitani, Chem. - Eur. J., 2005, 11, 4219-4226; (c) M. Kimura and K. Tanaka, Angew. Chem., Int. Ed., 2008, 47, 9768-9771; (d) Y. Matsubara, E. Fujita, M. D. Doherty, J. T. Muckerman and C. Creutz, J. Am. Chem. Soc., 2012, 134, 15743-15757; (e) Y. Matsubara, T. Kosaka, K. Koga, A. Nagasawa, A. Kobayashi, H. Konno, C. Creutz, K. Sakamoto and O. Ishitani, Organometallics, 2013, 32, 6162-6165; (f) J. Huang, J. Chen, H. Gao and L. Chen, Inorg. Chem., 2014, 53, 9570-9580.

12 (a) R. W. Callahan and T. J. Meyer, Inorg. Chem., 1977, 574581; (b) H. Hadadzadeh, M. C. DeRosa, G. P. A. Yap, A. R. Rezvani and R. J. Crutchley, Inorg. Chem., 2002, 41, 6521-6526; (c) M. G. Sauaia, R. G. de Lima, A. C. Tedesco and R. S. da Silva, J. Am. Chem. Soc., 2003, 125, 1471814719; (d) Z. N. da Rocha, M. S. P. Marchesi, J. C. Molin, C. N. Lunardi, K. M. Miranda, L. M. Bendhack, P. C. Ford and R. S. da Silva, Dalton Trans., 2008, 4282-4287; (e) A. C. Pereira, P. C. Ford, R. S. da Silva and L. M. Bendhack, Nitric Oxide, 2011, 24, 192-198; (f) T. A. Heinrich, A. C. Tedesco, J. M. Fukuto and R. S. da Silva, Dalton Trans., 2014, 43, 4021-4025; $(g)$ R. G. de Lima, B. R. Silva, R. S. da Silva and L. M. Bendhack, Molecules, 2014, 19, 9628-9654.

13 (a) T. Kinoshita, J. T. Dy, S. Uchida, T. Kubo and H. Segawa, Nat. Photonics, 2013, 7, 535-539; (b) R. Katoh and A. Furube, J. Photochem. Photobiol., C, 2014, 20, 1-16.

14 (a) R. Noyori and T. Ohkuma, Angew. Chem., Int. Ed., 2001, 40, 40-73; (b) R. Noyori, Angew. Chem., Int. Ed., 2002, 41, 2008-2022; (c) R. Noyori, Adv. Synth. Catal., 2003, 345, 15-32; (d) S. E. Clapham, A. Hadzovic and R. H. Morris, Coord. Chem. Rev., 2004, 248, 2201-2237; (e) A. F. Trindade, P. M. P. Gois and C. A. M. Afonso, Chem. Rev., 2009, 109, 418-514; $(f)$ R. Noyori, Angew. Chem., Int. Ed., 2013, 52, 79-92.

15 (a) P. Schwab, M. B. France, J. W. Ziller and R. H. Grubbs, Angew. Chem., Int. Ed. Engl., 1995, 34, 2039-2041; (b) H. Clavier and S. P. Nolan, Chem. - Eur. J., 2007, 13, 8029-8036; (c) G. C. Vougioukalakis and R. H. Grubbs,
Chem. Rev., 2010, 110, 1746-1787; (d) J. S. M. Samec, B. K. Keitz and R. H. Grubbs, J. Organomet. Chem., 2010, 695, 1831-1837; (e) S. P. Nolan and H. Clavier, Chem. Soc. Rev., 2010, 39, 3305-3316.

16 (a) C. M. Moore and N. K. Szymczak, Chem. Commun., 2013, 49, 400-402; (b) K.-N. T. Tseng, J. W. Kampf and N. K. Szymczak, Organometallics, 2013, 32, 2046-2049; (c) K.-N. T. Tseng, A. M. Rizzi and N. K. Szymczak, J. Am. Chem. Soc., 2013, 135, 16352-16355.

17 (a) D. K. Dutta and B. Deb, Coord. Chem. Rev., 2011, 255, 1686-1712; (b) C. S. Yi, J. Organomet. Chem., 2011, 696, 76-80; (c) I. Mellone, M. Peruzzini, L. Rosi, D. Mellmann, H. Junge, M. Beller and L. Gonsalvi, Dalton Trans., 2013, 42, 2495-2501.

18 (a) R. A. Leising, J. J. Grzybowski and K. J. Takeuchi, Inorg. Chem., 1988, 27, 1020-1025; (b) B. J. Coe, D. W. Thompson, C. T. Culbertson, J. R. Schoonover and T. J. Meyer, Inorg. Chem., 1995, 34, 3385-3395; (c) L. F. Szczepura, S. A. Kubow, R. A. Leising, W. J. Perez, M. H. V. Huynh, C. H. Lake, D. G. Churchill, M. R. Churchill and K. J. J. Takeuchi, Chem. Soc., Dalton Trans. Inorg. Chem., 1996, 7, 1463-1470; (d) W. J. Perez, C. H. Lake, R. F. See, L. M. Toomey, M. R. Churchill, K. J. Takeuchi, C. P. Radano, W. J. Boyko and C. A. Bessel, J. Chem. Soc., Dalton Trans., 1999, 2281-2292; (e) S. B. Billings, M. T. Mock, K. Wiacek, M. B. Turner, W. S. Kassel, K. J. Takeuchi, A. L. Rheingold, W. J. Boyko and C. A. Bessel, Inorg. Chim. Acta, 2003, 355, 103-115; (f) S. Sharma, S. K. Singh, M. Chandra and D. S. Pandey, J. Inorg. Biochem., 2005, 99, 458-466.

19 (a) B. P. Sullivan, D. J. Salmon and T. J. Meyer, Inorg. Chem., 1978, 17, 3334-3341; (b) B. P. Sullivan, D. Conrad and T. J. Meyer, Inorg. Chem., 1985, 24, 3640-3645; (c) J. P. Otruba, G. A. Neyhart, W. J. Dressick, J. L. Marshall, B. P. Sullivan, P. A. Watkins and T. J. Meyer, J. Photochem., 1986, 35, 133-153; (d) R. A. Leising and K. J. Takeuchi, Inorg. Chem., 1987, 26, 4391-4393; (e) R. A. Leising, J. S. Ohman and K. J. Takeuchi, Inorg. Chem., 1988, 27, 3804-3809; $(f)$ C. A. Bessel, J. A. Margarucci, J. H. Acquaye, R. S. Rubmo, J. Crandall, A. J. Jircitano and K. J. Takeuchi, Inorg. Chem., 1993, 32, 5779-5784; $(g)$ M. R. Churchill, L. M. Krajkowski, M. H. V. Huynh and K. J. Takeuchi, J. Chem. Crystallogr., 1997, 27, 589-597; (h) M. Salierno, E. Marceca, D. S. Peterka, R. Yuste and R. Etchenique, J. Inorg. Biochem., 2010, 104, 418-422; ( $i$ ) S. V. Litke, A. Y. Ershov and T. J. Meyer, J. Phys. Chem. A, 2011, 115, 14235-14242; (j) V. S. Miguel, M. Álvarez, O. Filevich, R. Etchenique and A. del Campo, Langmuir, 2012, 28, 1217-1221; (k) R. Araya, V. Andino-Pavlovsky, R. Yuste and R. Etchenique, ACS Chem. Neurosci., 2013, 4, 11631167.

20 (a) M. E. Marmion and K. J. Takeuchi, J. Chem. Soc., Dalton Trans., 1988, 2385-2391; (b) C. A. Bessel, R. A. Leising and K. J. Takeuchi, J. Chem. Soc., Chem. Commun., 1991, 833835; (c) N. D. Schley, G. E. Dobereiner and R. H. Crabtree, Organometallics, 2011, 30, 4174-4179. 
21 G. Nakamura, M. Okamura, M. Yoshida, T. Suzuki, H. D. Takagi, M. Kondo and S. Masaoka, Inorg. Chem., 2014, 53, 7214-7226.

22 J. Heinecke and P. C. Ford, Coord. Chem. Rev., 2010, 254, 235-247.

23 M. T. Gladwin, A. N. Schechter, D. B. Kim-Shapiro, R. P. Patel, N. Hogg, S. Shiva, R. O. Cannon III, M. Kelm, D. A. Wink, M. Graham Espey, E. H. Oldfield, R. M. Pluta, B. A. Freeman, J. R. Lancaster Jr., M. Feelisch and J. O. Lundberg, Nat. Chem. Biol., 2005, 1, 308-314.

24 R. A. Leising, S. A. Kubow and K. J. Takeuchi, Inorg. Chem., 1990, 29, 4569-4574.

25 P. Singh, J. Fiedler, S. Záliš, C. Duboc, M. Niemeyer, F. Lissner, T. Schleid and W. Kaim, Inorg. Chem., 2007, 46, 9254-9261.

26 (a) D. W. Pipes and T. J. Meyer, Inorg. Chem., 1984, 23, 2466-2472; (b) W. R. Murphy, Jr., K. J. Takeuchi, M. H. Barley and T. J. Meyer, Inorg. Chem., 1984, 25, 1041-1053.

27 R. G. de Lima, M. G. Sauaia, D. Bonaventure, A. C. Tedesco, L. M. Bendhack and R. S. da Silva, Inorg. Chim. Acta, 2006, 359, 2543-2549.

28 A. Altomare, G. Cascarano, C. Giacovazzo and A. J. Guagliardi, J. Appl. Crystallogr., 1993, 26, 343-350.

29 G. M. Sheldrick, Acta Crystallogr., Sect. A: Found. Crystallogr., 2008, 64, 112-122.

30 L. J. Farrugia, J. Appl. Crystallogr., 1997, 30, 565-566.

31 T. D. Fenn, D. Ringe and G. A. Petsko, J. Appl. Crystallogr., 2003, 36, 944-947.

32 M. J. Frisch, G. W. Trucks, H. B. Schlegel, G. E. Scuseria, M. A. Robb, J. R. Cheeseman, G. Scalmani, V. Barone, B. Mennucci, G. A. Petersson, H. Nakatsuji, M. Caricato, X. Li, H. P. Hratchian, A. F. Izmaylov, J. Bloino, G. Zheng, J. L. Sonnenberg, M. Hada, M. Ehara, K. Toyota, R. Fukuda, J. Hasegawa, M. Ishida, T. Nakajima, Y. Honda, O. Kitao, H. Nakai, T. Vreven, J. A. Montgomery, Jr., J. E. Peralta, F. Ogliaro, M. Bearpark, J. J. Heyd, E. Brothers,
K. N. Kudin, V. N. Staroverov, T. Keith, R. Kobayashi, J. Normand, K. Raghavachari, A. Rendell, J. C. Burant, S. S. Iyengar, J. Tomasi, M. Cossi, N. Rega, J. M. Millam, M. Klene, J. E. Knox, J. B. Cross, V. Bakken, C. Adamo, J. Jaramillo, R. Gomperts, R. E. Stratmann, O. Yazyev, A. J. Austin, R. Cammi, C. Pomelli, J. W. Ochterski, R. L. Martin, K. Morokuma, V. G. Zakrzewski, G. A. Voth, P. Salvador, J. J. Dannenberg, S. Dapprich, A. D. Daniels, O. Farkas, J. B. Foresman, J. V. Ortiz, J. Cioslowski and D. J. Fox, Gaussian 09 (Revision C.01), Gaussian, Inc., Wallingford CT, 2010.

33 A. D. Becke, J. Chem. Phys., 1993, 98, 5648-5652.

34 C. Lee, W. Yang and R. G. Parr, Phys. Rev. B: Condens. Matter, 1988, 37, 785-789.

35 (a) T. H. Dunning, Jr. and P. J. Hay, in Modern Theoretical Chemistry, ed. H. F. Schaefer, III, Plenum, New York, 1976; (b) P. J. Hay and W. R. Wadt, J. Chem. Phys., 1985, 82, 270283; (c) P. J. Hay and W. R. Wadt, J. Chem. Phys., 1985, 82, 299-310; (d) D. Andrae, U. Haeussermann, M. Dolg, H. Stoll and H. Preuss, Theor. Chim. Acta, 1990, 77, 123.

36 M. Cossi, G. Scalmani, N. Rega and V. Barone, J. Chem. Phys., 2002, 117, 43-54.

37 (a) M. E. Casida, C. Jamorski, K. C. Casida and D. R. Salahub, J. Chem. Phys., 1998, 108, 4439-4449; (b) R. E. Stratmann, G. E. Scuseria and M. J. Frisch, J. Chem. Phys., 1998, 109, 8218-8224; (c) R. Bauernschmitt and R. Ahlrichs, Chem. Phys. Lett., 1996, 256, 454464.

38 P. T. Burks, J. V. Garcia, R. GonzalezIrias, J. T. Tillman, M. Niu, A. A. Mikhailovsky, J. Zhang, F. Zhang and P. C. Ford, J. Am. Chem. Soc., 2013, 135, 18145-18152.

39 (a) J. G. Calvert and J. N. Pitts, Photochemistry, J. Wiley \& Sons, New York, 1967, pp. 783-786; (b) G. Malouf and P. C. Ford, J. Am. Chem. Soc., 1977, 99, 7213-7221.

40 C. F. Works, C. J. Jocher, G. D. Bart, X. Bu and P. C. Ford, Inorg. Chem., 2002, 41, 3728-3739. 